Özet:

Kullanıcı istek ve ihtiyaçlarını daha iyi karşılayabilecek ürünler ortaya çıkartmak isteyen endüstri tasarımcısının, ürünlerin taşıyacağı iletileri iyi oluşturması gerekmektedir. Bunun için bağlam ve amaca uygun işaretler tasarlanarak ürünlere yerleştirilmelidir. Ürün tasarımcısının çok açık işaretler taşıyan ürünler ortaya çıkartabilmesi için kullanabileceği yöntemler, detaylı şekilde işlenmiş bir konudur. Göstergebilime ait çeşitli araçlar, endüstri ürün tasarımına uygulanmaya çalışılmıştır. Eğretileme bu amaç için kullanılırlığı günümüze değin pek detaylı araştırılmamış bir kavram-araçtır. Eğretilemenin ürün biçimsel özelliklerinin belirlenmesinde kullanımı, tasarımcıya önemli olanaklar sunabilir. Yoğun olarak elektronik tabanlı modern ürünler, fiziksel özellikleri ve mekânik parça kullanımlarının az olması nedeni ile çok çeşitli şekillere rahatlıkla girebilirler. Bu da ürün tasarımcısının, teknik gereksinimlere takılmadan, eğretilemelerden istediği gibi faydalanarak, sahibi ile duygusal kültürel bağlar kuran, kullanıcı dostu ürünler tasarlayabilmesini kolaylaştıracaktır.

\section{Summary:}

The industrial designer who wants to design a product that will fulfill the needs and desires of a modern consumer should concentrate well on the messages his or her products shall convey. For this purpose, signs which are suitable for the context and designer's intentions must be created and used on the product very carefully. The methods that can be used by a product designer to create products with clear signs have been the subject of many researches. One of the conceptual tools which hasn't been academically researched in detail so far is the metaphor. Usage of metaphors in electronic products can give many opportunities to the industrial designer.

Though they don't incorporate any mechanical parts and their physical properties are suitable, electronic systems can take many different shapes and fit into many different volumes. This gives the designer a good opportunity to give whatever shape necessary to his or her product by using different metaphors. Anahtar Kelimeler:

Endüstri, Ürün, Tasarım, Benzetme,

Eğretileme

Keywords:

Industry, Product, Design, Resemblance,

\title{
Eğretilemeli Anlatımlar ve Tasarım Yaklaşımı olarak Yöntemli Kullanımı
}

\author{
Doktora makalesi \\ Özkal Özsoy, Danışman Prof. Dr. Ŏguz Bayrakçı
} MSGSÜ Mimarlık Fakültesi, Endüstri Ürünleri Tasarımı Bölümü

*MSGSÜ, Fen Bilimleri Enstitüsü, Endüstri Ürünleri Tasarımı Anabilim dalı “Endüstri tasarımı ĕ̆retilemeli anlatımlar ve tasarım yaklaşımı olarak yöntemli kullanımı” başlıklı tezinden Mayıs 2009 tarihinde oluşturulan bir makaledir. Makale metni 22.06.09 tarihinde dergiye ulaşmış, 22.07.09 tarihinde basım kararı alınmıştır. Makale ile ilgili tartışmalar 31.06.2011 tarihine kadar dergiye gönderilmelidir.

\section{Endüstri Ürünü - Kullanıcı İletişimi}

Bir ürünün kullanıcılar tarafından tercih edilebilmesi için sadece basit ihtiyaçlarıkarşılaması artık yeterli değildir. Bazı kullanıcılar ürün tercihinin belirlenmesinde değişik, yararlı, akıllı özellikler ararken, bazıları ise öncelikle ürünün kendileri ile kurduğu bağdan etkilenmektedir. Bu bağ kullanıcının geçmişi, kültürü, eğitim düzeyi ve benzeri etkenlerle ilişkili olabilir.

Ürünlerin başarısını arttırmak için en etkili gerekliliklerden biri de kullanıcı ve ürün arasında bir bağ kurulmasıdır. Ürünleri daha istenir kılan öğelerin ortaya çıkartılması, bir ürünün ulaştığı başarı düzeyine, hem ürünün diğerleri arasında öne çıkması hem de satın alındıktan sonra başarı ile kullanılabilmesi açısından olumlu etki yapacaktır. Bu bağ, ürünün taşıdı $\breve{g}$ iletilerin iyi belirlenmesi ile kurulabilir.

Kullanıcı istek ve ihtiyaçlarını daha iyi karşılayabilecek ürünler ortaya çıkartmak isteyen endüstri tasarımcısının, ürünlerin taşıyacağı iletileri iyi oluşturması gerekmektedir.

Bunun için bağlam ve amaca uygun işaretler tasarlanarak ürünlere yerleştirilmelidir. Ürün tasarımcısının çok açık işaretler taşıyan ürünler ortaya çıkartabilmesi için kullanabileceğ i yöntemler, detaylı şekilde işlenmiş bir konudur. Göstergebilime ait çeşitli araçlar, endüstri ürün tasarımına uygulanmaya çalışılmıştır. Eğretileme ise bu amaç için kullanılırlığı günümüze değin pek detaylı araştırılmamış bir kavram-araçtır.

Eğretilemenin ürün biçimsel özelliklerinin belirlenmesinde kullanımı, tasarımcıya önemli olanaklar sunabilir. Yoğun olarak elektronik tabanlı modern ürünler, fiziksel özellikleri ve mekânik parça kullanımlarının az olması nedeni ile çok çeşitli şekillere rahatlıkla girebilirler. $\mathrm{Bu}$ da ürün tasarımcısının, teknik gereksinimlere takılmadan, eğretilemelerden istediği gibi faydalanarak, sahibi ile duygusal kültürel bağlar kuran, kullanıcı dostu ürünler tasarlayabilmesini kolaylaştıracaktır. 
Bir ürünün değeri, kullanıcının ürünle bağdaştırdı ̆̆ 1 anlam ve değerler kadardır. Örneğin güçlü bir marka, ürünün değerini arttırabilecek özelliklere örnektir. Üründe kullanılan başarılı eğretilemeler de bu özellikler arasında yer alabilir. Fiziksel bir üründe eğretilemeleri kullanmanın çeşitli yolları vardır. Kullanıcı bir ürünü tüm duyu organlarını kullanarak algılayabilir, bu da üründeki eğretilemenin görsel, işitsel, kokusal, tatsal ve doğrudan fiziksel etkileşim temelli olabileceği gerçeğini ortaya çıkartır.

\section{2.Ürünün Tasarım Dili}

Tüm ürünler, kullanıcıları ile iletişim halindedir. Bu iletişim birçok değişik ortam ve düzeyde meydana gelir. Bazı ürünler işlevselliklerini vurgular veya bir duyguya gönderme yaparken, bazıları bir öykü anlatıyor olabilir. İletişimde aktarılan veri ne olursa olsun, tüm ürünler, bilinçli veya rastgele oluşan bir dili konuşurlar. Ürün tasarımcısı bu dili yorumlayıp, gerektiğinde değisşikliğe uğratarak kendi tasarımında yer almaya uygun hale getirir ve böylece kendi özgün "tasarım dilini" ortaya çıkartır. Üründe istenilen iletilerin verimli olarak aktarılması, istenmeyen iletilerin de en aza indirilmesi için özenle oluşturulan tasarım dili ürünün biçimsel özellikleri ile ortaya konulduğuna göre "tasarım biçim dili" olarak adlandırılması uygun olacaktır.

Bir kavramın dildeki anlatımında, seçilen uygun kelimelerin bir cümle şeklinde düzenlenerek kullanılmasına benzer şekilde, tasarım biçim dili bileşenleri de ürün bağlamında iletişim sağlayabilmek için özenle seçilerek düzenlenir. Dildeki kelimeler gibi, tasarımdaki biçim dili bileşenlerinin de seçimi, fikrin doğru iletilmesi için çok önemlidir. Bir cümledeki her kelime çeşitli duygular ortaya çıkmasını sağlayacak yan anlamlar taşıyabilir veya cümlenin anlamını değiştirebilecek farklı tonlarda olabilir. Benzer şekilde tasarım biçim dili bileşenleri de değişik duygular ya da yan anlamlar taşıyabilir. Tasarım biçim dili bileşenlerinin dikkatli seçimi ve düzenlenmesi, ürünün iletiyi kullanıcıya tam hedeflendiği gibi aktarabilmesi için gerekli koşuldur.

Tasarım biçim dili bileşenlerini seçme aşamasında olan bir endüstri ürünleri tasarımcısının, kullanıcı zihnindeki sınıflandırma süreci hakkında bilgi sahibi olması ve seçimlerini buna göre yapması, tasarladığı ürünün kullanıcıyla daha verimli bir etkileşim kurmasına yardımcı olacaktır.

Kullanıcının, günlük hayatında karşılaştı̆̆ bilinmeyenleri algılamada kullandığ çeşitli hazır araçlar vardır. Eğretileme de bunlardan biridir. İnsanın çevresini anlamasında önemli bir kavram olan eğretilemenin tasarımda bilinçli kullanımı, istenilen iletinin kullanıcıya daha akıcı ve etkili bir şekilde aktarılmasına yardımcı olabilir. Tasarımcı tarafından, üründe kullanılan tasarım biçim dili bileşenlerini yönlendiren bir eğretilemeli kavramın bilinçli şekilde seçilmiş olması, ürünün kullanıcısı ile kurduğu bağlantının başarısını doğrudan etkileyecektir.

\section{3.Ĕ̈retileme Kavramı}

İngilizce'deki metaphor kelimesi, Yunanca'da “öte'ye taşımak", "iletmek" anlamina gelen metaphora (metaphora) kelimesinden türemiştir. Bu kelime modern Yunanca'da hâlâ kullanılmaktadır. Antik Yunan'da “metaphor” ikinci bir anlama daha sahiptir: Aristo, bu ikinci anlamı, "Metafor, kendinden başka bir şeyi tasvir eden bir varlığın kullandı $\breve{g}_{1}$ araçtır" şeklinde anlatmıştır (Aristo, Şiirler). Aslen kendi de metaforik yani eğretilemeli olan bu tanım İngiliz ve birçok Avrupa 
dillerine uyarlanarak kullanılmıştır.

Eğretileme, Türkçe'de metafor olarak da

kullanılmaktadır.

Eğretilemenin Türk dil bilimindeki

karşılığı olan istiare, bir sözcüğü kendi

anlamı dişında kullanarak, bir şeyi

benzediği başka varlığının adıyla anma

sanatı olarak anılır. İstiare terimi

günümüzde yavaş yavaş yerini eğretileme terimine bırakmaktadır. Batı kökenli metafor ile doğu kökenli istiare/eğretileme arasındaki fark, doğu düşüncesi ile batı düşüncesi arasındaki farklılı̆̆ı ortaya koyar. İstiare, are'ye, ariyete'e yani ödünç almaya dayanır: Ödünç alma, birinden eğreti bir şey alma; bir kelimenin anlamını "geçici olarak" bir başka kelime için kullanma, bir sözün gerçek anlamını kaldırarak, benzerliği olan diğer anlamı eğreti olarak vermedir. Bu bakımdan hem mecaz hem de benzetme özellikleri taşır. Eğretileme ise, istiarenin kelime anlamının Türkçe'ye aktarılmasıdır. Yerini bulmamış, uygunsuz, temelli olmayan anlamındadır. Çalışmamızda İngilizce'deki metafor kavramının tek ve derin anlamı dışında başka türlü benzetmeler de eğretileme başlığı altına alınarak incelenmiştir.

\section{4. Ĕ̆gretilemenin gelişimi}

Eğretileme 1970'lerin sonlarına ve

Şekil: I 1980’lere kadar, dilbilimci ve

Çapraz alan eşleștirme araştırmacıların çoğu tarafından

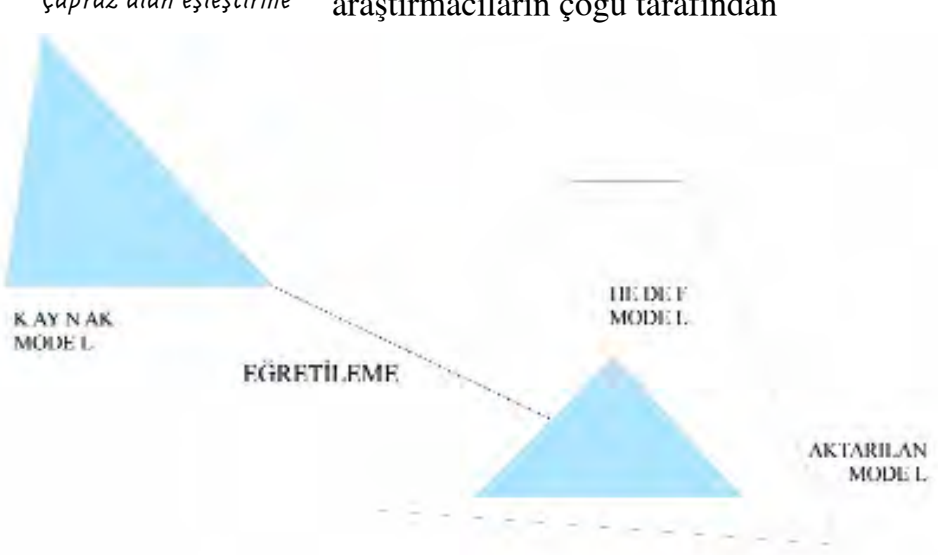

konuşmanın normal olmayan bir bölümü, dekoratif bir dil oluşturma amaçlı şiirsel bir özenti gibi görülmüş, eğretilemenin "normal" dil kullanımı ile açıklanması gerekliliği vurgulanmıştır.

$\mathrm{Bu}$ tarihlerden sonra yapılan çalışmalar sayesinde eğretilemenin sadece dilin bir parçası değil, genel olarak düşünce sistemimizin bütünüyle ilgili olduğu ve "bir alanı, bir başkasını kullanarak kavramsallaştırma" amacıyla kullanılabileceği görüşü, giderek daha fazla kabul görmeye başlamıştır. $\mathrm{Bu}$ düşünceye göre eğretileme düşün sistemimizde son derece yaygındır ve eğretileme sayesinde binlerce alan, başka alanlarla "eşleşir". Hatta herhangi bir soyut kavram hakkında eğretileme kullanmadan konuşabilmek hemen hemen olanaksızdır.

Bilimin kavramlarını anlamak ve geliştirmek için eğretileme kullanımı, belki de bilim tarihi boyunca geçerli olmak üzere oldukça yaygındır: Bohr'un atom modeli güneş sisteminin yapısına dayanmaktadır, Maxwell bir elektrik alanını bir sıvının özelliklerini kullanarak anlatmıştır. Sesin ilerleyişi, üretilen ilk teorilerden beri dalgalara benzetilerek anlatılagelmiştir. Düşünülenin aksine, bilim edebi dilin örnekçesi değildir; bilimdeki ilerlemelere yardımcı olan modelleme süreci içinde büyük öneme sahip olan asıl kavram eğretilemedir. Roland Barthes de eğretileme hakkında, "bir şeye benzemeyen biçim yoktur ve olamaz; insanlık benzerlik kurmaya mahkumdur" yorumunu yapmıştır.

"Çapraz alan eşleştirme" (Cross-domain mapping) fikri, günümüz eğretileme düşüncesinde merkezi öneme sahiptir. Yeni varlıkları anlama yöntemimiz, onları bildiğimiz varlıklar cinsinden hayal etmemize dayanmaktadır. Eğretilemeler 
bize, bildiğimiz somut varlık ya da deneyimleri alıp, bilmediğimiz varlıklar ya da soyut kavramlar yerine kullanmamız, böylece onlara yapı ve anlam kazandırabilmemiz için uygun doğal modeller olurlar. (Şekil 1)

Eğretileme, ürünlerde de bilinçli ya da bilinçsizce hep kullanıla gelmiştir ve bu kullanımın daha bilinçli hale getirilmesi, ürün başarımını olumlu etkileyecektir. İnsan zihnindeki eğretilemeli yapının araştırılıp endüstri tasarımı sürecinde bu zihinsel yapıya uyum sağlayacak değişiklikler yapılması, tasarım süreci sonucunda ortaya çıkan ürünün zihindeki algılanması sürecini kısaltabilir. Özellikle dijital elektronik ürünler ile ilgili anlamsal sorunlar, eğretilemeli çözümlerle daha kolay şekilde aşılabilecektir

\section{Insan zihninin yapısı ve ĕgretilemenin zihinde işlenişi}

Paul Mac Lean, sara hastaları üzerinde yaptığı çalışmalarda elde ettiği bilgilere dayanarak, beynin üç ana bölümden oluştuğu fikrini ortaya atmıştır (The Triune Brain, 1952-1960). Lean'e göre, R-Complex, limbic-system ve neo-cortex olarak adlandırdı ̆̆ 1 üç bölüm birbirinden bağımsız zeka, zaman-uzay kavram ve belleğe sahiptir. Kabaca, R-Complex omurilik soğanı-omurilik, limbic-system beynin orta bölümü ve neo-cortex de beynin iki yarı küresinin dış katmanından oluşmaktadır. Bu bölümlerden en eski olanı, ilkel sürüngen beyni ile benzer özellikler taşıdığı için Lean tarafından "sürüngen beyni" olarak adlandırılan RComplex'tir.

Dokunma, basit düzenleme, motor kontroller, hayatta kalmaya yönelik basit düzeyde hisler-refleksler, aynı düzeyde bellek işlevleriyle vücudun nefes, kalp atışı gibi otonom sistemlerini kontrol eder, uyku dahil sürekli aktiftir. Beynin bir üst düzeydeki parçası, limbic-system, Lean tarafından "ilkel memeli beyni” olarak adlandırılmıştır ve evrim sürecindeki ilk memeli olan primatların beyinleri ile ortak özellikler taşır. Sürüngen beynine göre daha karmaşık bir bellek ve mantık sistemi içerir, duyguların kaynağ içgüdüsel davranışları bir üst kademeye taşır. Tek başına bir karar almayan bu bölüm, bir üst bölüm ile yoğun iletişim halindedir. Lean'ın neo-cortex olarak adlandırdığ 1 en üst beyin bölümü ise daha üst düzey memelilerin ve insanın beyin yapisında bulunur. İnsan beyninde kapladığ 1 hacim, tüm beynin yaklaşık 2/3'ünü oluşturur. Neo-cortex daha karmaşık düşünce, mantık, özel yetenekler ve bunlara ait belleği barındırır. Beyin bölümleri arasında yönetimsel hiyerarşi vardır. Hayatta kalma amacı ile R-Complex'in ürettiği kararlar, limbic-system'in ürettiği duygusal dürtülerin, duygusal dürtüler de

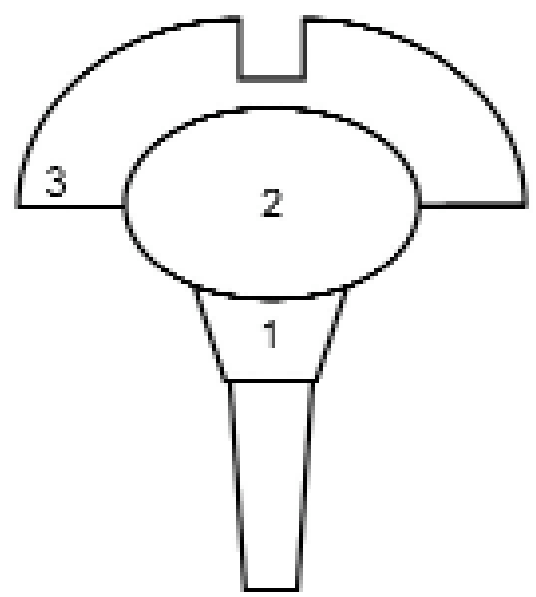

Şekil: 2

Ü̧ bölümlü beyin yapısı. neo-cortex'in ürettiği zeka, yaratım ve kültüre dayalı sonuçların önüne geçebilir. (Şekil 2)

Her tür sosyal ve kültürel karşılaşma, insan beynine gelen ve mevcut bilgilerdenfaydalanılarak çözümlenmesiyorumlanması gereken yeni bir bilgi 
kümesidir (Jerome Feldman, 2006). İnsan beyni, yaklaşık 10-100 milyar arası sinir hücresinden oluşur, her hücre 1000-10000 arası başka sinir hücresi ile çeşitli farklı türde bağlantılara sahiptir. Bu bağlantılar, çeşitli elektro-kimyasal yollarla hücreler arası haberleşmeyi sağlar. (Şekil 3)

Beyindeki çalışma sistemi büyük oranda paralel hesaplamalara dayanır. Herhangi bir hareket veya düşünce, milyarlarca nöronun önemli bir kısmında hareketliliğe neden olur.

Sürekli bir bütünsel oto-kontrol altında çalışan bu paralel yapıda her bölüme ne yapması gerektiğini söyleyen bir merkezi kontrol sistemi yoktur. Benzer şekilde öğrenme sürecinin de bir denetleyicisi yoktur. Sinirsel hesaplamalar, beynin anlık elektrokimyasal durumu ile giriş verileri arasında sürekli olarak eşleşmeler kurulması, bunların sınıflandırılarak, en güçlü-başarılı olanın seçimine dayalıdır. Dolayısıyla beynin, büyük oranda paralel yapılı bir "en iyi eşleşmeler" bilgisayarı olduğu söylenebilir. İki nöron arasındaki elektro-kimyasal iletişim saniyenin yaklaşık 1/1000 'inde (1x10-3 = 1 milisaniye) gerçekleşmektedir (Feldman, From Molecules to Metaphors, 2006, 50). Dış ortam etkilerine en hızlı tepki süresi yaklaşık100/1000 saniye olduğuna göre, bu tepkinin yaklaşık 100 nöron adımında gerçekleştiği söylenebilir. Yani bir arkadaşımız bize seslenip bizden elimizi kaldırmamızı istediğinde, bunu algılayıp elimizi kaldırma hareketine başlamamız
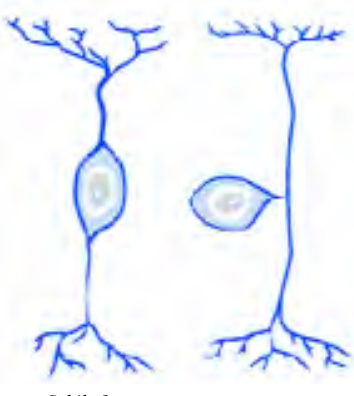

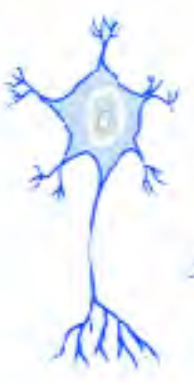

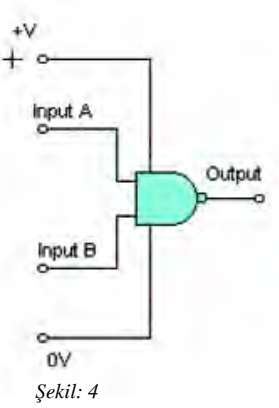

arasındaki süre en az 100 milisaniye olacaktır. İki nöron arası en basit bir iletişimin bile 1 milisaniyede tamamlanabildiği düşünülürse, sesin kulakta algılanması, elektro-kimyasal sinyallerin beyne iletimi, konuşmanın taşıdığı anlamın çözülmesi, gerekli karar mekânizmalarının çalışması, motor komutlarının verilmesi, komutların kaslara ulaşması gibi karmaşık bir olaylar dizisinin, bu kadar kısa sürede gerçekleştirilebilmesinin tek yolu, beynin bir nöron adımına yetecek sürede, büyük seviyede paralel nöron iletişimi sayesinde aslında milyarlarca nöron adımını yürütmesidir. Bu çalışma sistemi, bilgisayar mühendisliğinde geniş olarak işlenmiş, beynin sinir ağı yapısını taklit eden bilgisayarlar tasarlanmıştır. Bilgisayar mühendisliğinde, seri ve paralel bilgi işlem sistemleri, çok büyük ölçüde paralel bilgi işlem (massively parallel computing), yapay sinir ağları, sıklıkla duyulan kavramlardır. Bilgisayar sistemlerinin nöronların beyni oluşturmasına benzer biçimde temel bir sayısal yapıtaşının tekrarlanarak inşası, bilişimin ilk günlerinden beri uygulanmaktadır. Örneğin; yeterli sayıda olmak şartı ile sadece NAND (ve değil) kapısı kullanılarak bilgisayarın hemen tüm sayısal hesaplama sistemleri inşa edilebilir. (Şekil 4) Bu inşa yöntemi, NAND'den başka tür mantık kapıları kullanılarak da gerçekleştirilebilir. Tam olarak kanıtlanmamış olmakla beraber, görüntülerin ve dolayısıyla ürün biçimlerinin, gözden gelen iki ve üç boyutlu görsel yapı korunarak beyinde saklandı ̆ı, hayatta karşılaşılan biçimlerle görsel üst üste konma eşleştirmeleri gerçekleştirildiğine dair bulgulara erişilmiştir. Gözden gelen görüntü verisinin, beyindeki nöron bağlantıları üzerine iki boyutlu yansitılarak saklandığı 
- işlendiği varsayımına dayanılarak geliştirilmiş, aynı yapıyı taklit eden paralel bilgisayar donanımları, görüntü işleme amacıyla yıllardır kullanılmaktadır.

Araştırmalar, hareket etmede işlev gören motor sinyalleri üreten sinir hücrelerinin birçoğunun, aynı tür hareketin algılanması sırasında da elektro-kimyasal hareketlilik gösterdiğini kanıtlamıştır. Örneğin bir şeyi el ile kavrama ile ilgili bir görüntü izlediğimizde, elle kavrama ile ilgili motor işlevleri yöneten beyin devrelerinde büyük ölçüde elektrokimyasal hareketlilik görülür. Eğer bu ölçü, tüm devreler düzeyine yayılmış ise, zaten el ile kavrama olayı gerçekleşiyor demektir (Buccino, 2001). El ile kavrama ile ilgili görsel işitsel bir duyum alan insan beyni, bu olayı en kolay şekilde algılayabilmek için, zihninde olayın kendi eli tarafından gerçekleştirildiğini canlandırır (Hawk 2004, Tettamanti 2005). Buna göre,

yeni karşılaşılan bir endüstri ürününün, kullanıcı tarafından algılanabilmesi için, zihinde canlandırılacak bir olayda yer alabilecek biçimlere sahip ya da bunlara benzetilebilir yapıda olması, ürünün kolay anlaşılması, benimsenmesi ve kullanılabilmesi için önemlidir. Fikirler, kavramlar, biçimler, sesler, kokular vs. de beyinde sürekli olarak işlenmekte ve çeşitli sinirsel hareketliliğe yol açmaktadırlar. Bu tür kavramların anlaşılması ve işlenebilmesi için kullanılan beyin devre ve sistemleri tam olarak bilinmemekle beraber, eldeki ipuçları beyinde her biçim, kelime, kavram, çizim vs. için bir veya birden fazla kararlı donanımsal bağlantı şablonunun bulunduğunu göstermektedir. Öğrenme süreci ise nöronlar arasındaki bu bağlantıların daha güçlenmesinden ibarettir. Nöronlar arası trilyonlarca bağlantı, öğrenme öncesinde de sonrasında da aynı sayıdadır. Bir kavram, kelime ve biçimin ilk görülmesi ile beyinde hareketlenen nöron grubu, aynı kavram, kelime veya biçimin sonraki görülmesi veya düşünülmesi ile tekrar hareketlenir. Bu nöron grubu, bu hareketlenme iletişimini ne kadar sik gerçekleştirirse, hücrelerin bilgi iletmede kullanılan kimyasal ve elektriksel özellikleri o düzeyde gelişecek ve sinyallerin iletilme hızı ve gücü artacaktır. Böylece, bu grubu hareketlendiren girişlerle karşılaşıldığında, bu girişlerin algılanması öncelikle daha kolay, sonrasında daha hızlı hale gelecektir. Daha güçlü sinyaller, bunlara bağlı diğer zihinsel karar almalara daha güçlü etki edecek, zincirleme bir zihinsel hızlanma sağlayacaktır. Bu durum, insan zihnindeki öğrenme ve hatırlama olgularını basitçe açıklamaktadır (Feldman 2006).

Bir ürünle karşılaşıldığında, bu ürüne ait biçimler, beyinde bazı sinirsel bağlantıları hareketlendirecektir. Ürünle karşıllaşmanın, bağlantılarda yarattığı güçlenme, ürün biçiminin beyine iki veya üç boyutlu bir harita olarak kaydedilmesi anlamına gelecek, karşılaşmada biçimin yanında gelen diğer bilgiler de bu biçim ile eşleştirilecektir. Biçimle sonraki karşılaşmalarda, artık daha da güçlü bağlantılara sahip olan sinir ağı şablonu daha hızlı hareketlilik gösterecek ve ürünün çevresindeki kavramlarla birlikte daha kolay algılanmasını sağlayacaktır. İnsanlar, ilk karşılaştıkları biçim veya kavramları, kendi vücutlarını da dahil ettikleri eğretilemeli canlandırmalarda kullanarak hesaplar-anlar. Bir biçim ve kavram ile belirli bir sıklığın üzerinde karşılaşan insan zihni, artık bu biçim-kavram'ın eğretilemeli anlamını hesaplamak veya düşünmek yerine, basitçe bellekten daha önce hesapladığı 
Şekil: 5

Ürünün eğretilemeli algılanışı

(Srinivas Narayanan, 1997 dan ürün tasarımına uyarlanmiştir.)

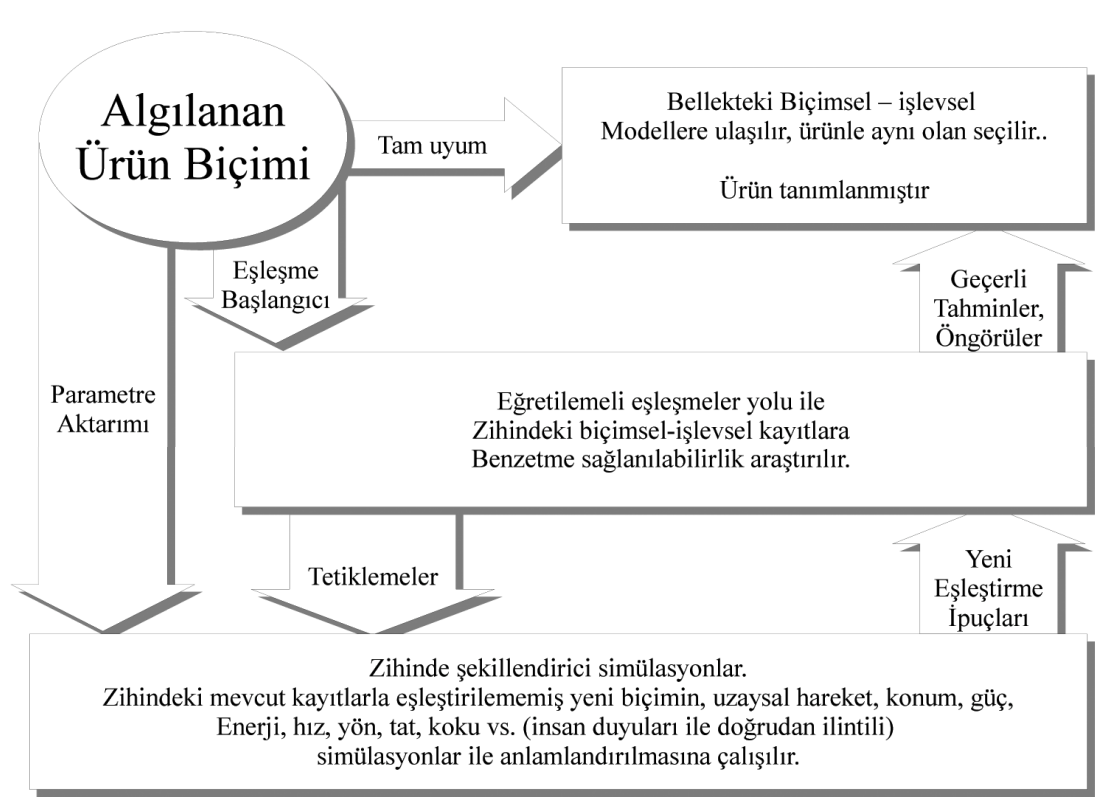

anlamı çekmek işlemini gerçekleştirir

(Bowdle, Wolff \& Boronat, 2001).

Eğretilemenin gücü, zihindeki özgün ve çok boyutlu kavramsal bağlantılar kurulmasına dayalı çalışma biçiminden aynen faydalanmasından gelmektedir; Kaynak ortam ile hedef ortam arasındaki eğretileme bağlantısının kurulmasından sonra insan zihni, belleğinde kayıtlı kaynak ortam özelliklerini, daha soyut ve bilinmeyen hedef ortama otomatik olarak aktarmaya çalışır (Feldman, 2007). Bu bilgi, ürünün semantik algılanışının basit yapısına uyumlu olmakla beraber, bu yapının çok daha ileri düzeyde anlaşılmasını sağlayabilecek potansiyele sahiptir. (Şekil 5)

\section{6. Ĕ̆retilemenin çevresi ile ilişkileri}

Eğretileme, doğru kullanıldığında tasarımcılar için faydalı, güçlü bir kavram-araçtır.

Bununla birlikte, eğretilemenin yanlış kullanılması, eğretileme kullanımına hiç çaba gösterilmediği durumdan daha kötü sonuçlar ortaya çıkarabilir. Uygun şekilde kullanılmış eğretileme, alıcıya bilmediği yeni bir kavramla ilgili detayları, bildiği bir kavram cinsinden anlatır. Bu süreç birkaç kere meydana gelir ve sonrasında alıcı zihindeki öğrenme özelliği nedeniyle, eğretileme bir anlam olarak bellekteki yerini alır ve bir daha fark edilmeyecek bir konuma geçer; artık eğretileme özümsenmiş ve kabul görmüştür. Tekrar fark edilmesi için özel çaba gerekecektir. Bu, kavramı tanıyan kişilerin dış katmandaki eğretilemelerle vakit kaybetmeden doğrudan daha önemli alt detaylara ulaşabilmelerine olanak veren olumlu birözelliktir. Eğretilemenin uygun şekilde seçilmediği durum ise, eğretilemenin tanınma aşamasında farklı yorumlar oluşturabileceği için, asıl anlatılmaya çalışılan kavramın yanlış aktarılmasına yol açabilir.

Farklı kültürlerin, özellikle zaman gibi soyut konularda sahip oldukları kavramsal çerçeveler birbirlerinden farklı olabilir. Birden fazla kültüre yayılan eğretilemelerin seçimi yapılırken bu konuya dikkat edilmelidir. Eğretilemeler kültüre özel olmakla kalmaz, sıklıkla o 
kültüre sahip aynı toplum içindeki belirli alt gruplar arasında da değişiklik gösterebilir.

Örneğin geleneksel bir telefonu hiç görmemiş bir toplum için geleneksel telefon şeklindeki bir sayısal telefon hiçbir anlam taşımayacaktır.

Eğretileme kavramsal aracı, içerisinde kullanıldığı bağlama göre tamamen farklı anlamlar taşıyabilir. Bir bağlam içinde anlamlı olan bir eğretileme, başka bir bağlamda tamamen ilgisiz kalabilir ya da değeri olmayan bir anlam taşıyabilir. Etki sağlamak için özellikle aksi eğretilemeler seçmiyorsanız, bir üründeki eğretilemeler, birlikte kullanılacakları diğer olgulara uygun olmalıdır. Üründeki eğretileme, içerisinde yer aldı ̆̆ tasarımı zenginleştirmelidir. Ürün tasarımını zenginleştiren eğretilemeler, ürün ve etrafındaki diğer olguların büyük çoğunluğu ile doğru ve güçlü bağlantılar kurulabilenlerdir.

Eğretileme, kişinin kendisine tanıdık gelmeyen işlevsellikten kolaylıkla anlam çıkarabilmesine ve bunları kolay öğrenmesine yardımcı olmak amacıyla kullanılabilir. Bir işleve veya eyleme yönelik eğretileme, o işlevin çeşitli alt düzeylerini de üzerinde taşıyabilir.

$\mathrm{Bu}$ nedenle eğretilemenin yanlış seçildiği, belli bir işlevselliğin bir eğretilemeye sıkıştırılmaya çalışıldığı durumlar, öğrenme-benimseme sürecinde istenmeyen olumsuz sonuçlar doğurabilir. İdeal durumda eğretilemeler kavramları destekler özellikte olmalıdır, kavramlarca desteklenmeleri ya da kavramın ta kendisi olmaları, eğretilemelerin sağlayacağı faydaları ortadan kaldırabilir.

\section{Endüstri Ürünlerinde Ĕgretileme}

Endüstri ürünlerinde eğretileme kullanımını iki ana bölümde incelemek olasıdır; ilki, doğrudan endüstri ürünü bünyesinde, tasarımında ve yapısında yer alan, kullanıcıya çeşitli iletiler aktaran biçimsel eğretilemedir. İkincisi ise, endüstri ürününün tasarım süreci içerisinde kullanılan, kendi nelikliği ile

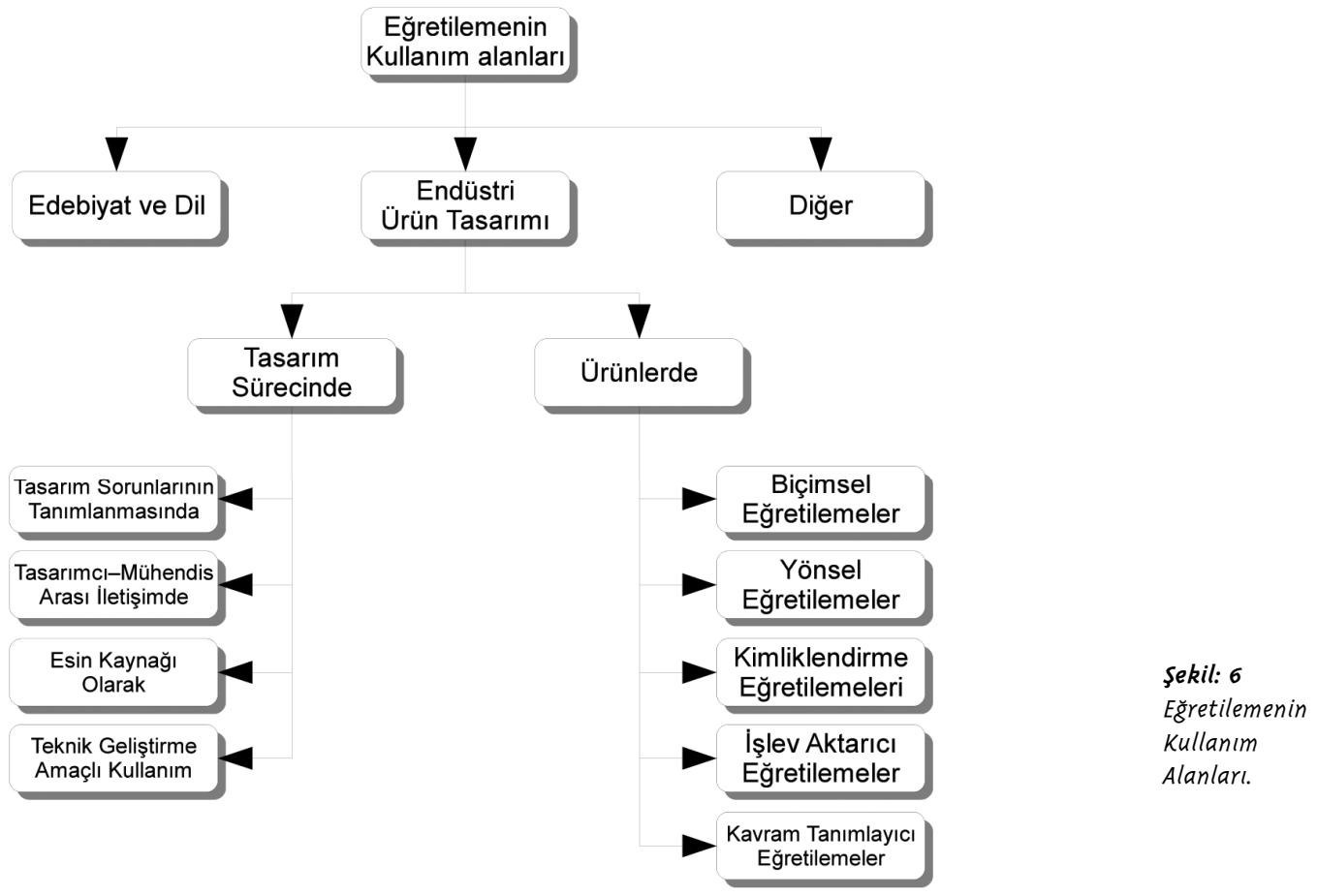

102 Sayı 8, Aralık 2009 
endüstri ürününde yer almayan fakat ürün tasarımı sürecinin düzenlenmesinde

kullanılan eğretilemedir. (Şekil 6)

Düşünce için kelimeler ne anlam taşıyorsa, eğretileme için de tasarım biçim dili bileşenleri benzer anlam taşır. Zihinsel sınıflandırma sürecinin önemli bir parçası olan eğretileme, kişilerin nesneleri birbirleriyle karşılaştırmalarına izin vererek dışsal olguları daha iyi anlmalarını sağlar. Eğretileme günlük hayatımızın önemli bir parçasıdır ve kelimelerin kolayca ötesine gidebilen 'şey'ler üzerindeki zihinsel faaliyetlerimizi şekillendirir; algılayışımız, düşüncelerimiz ve hareketlerimiz üzerinde etkileri vardır. Eğretileme sadece dilde değil, düşünce ve eylem düzeyinde de çokça karşımıza çıkar.
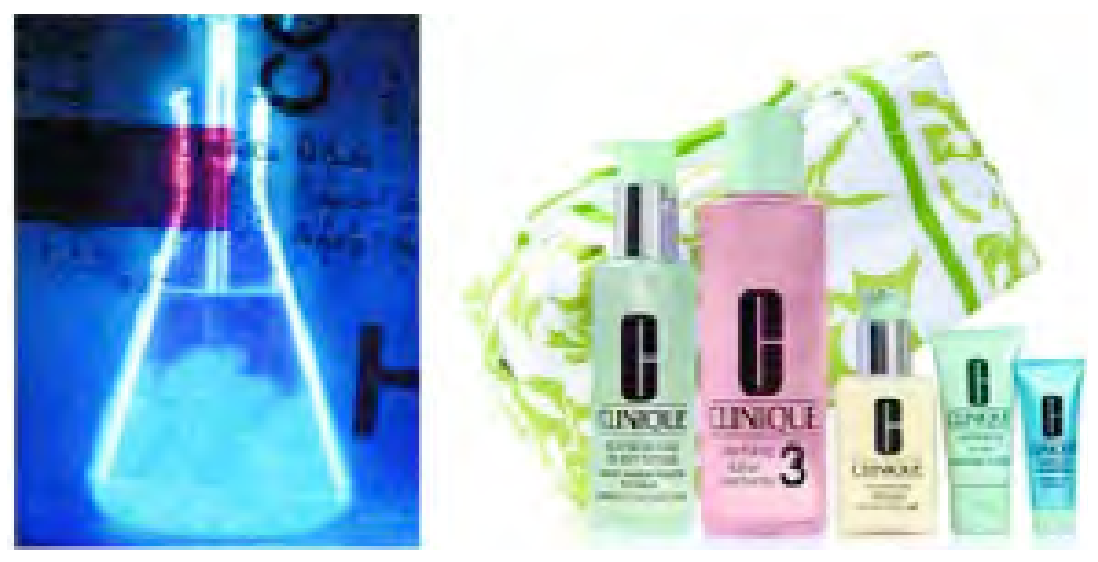

şekil: 7 Düşünce ve eylemlerimizin temelini Clinique markası; oluşturan kavramsal sistemimiz, temel eğretilemesi. olarak eğretilemeli yapıdadır. Eğretileme sadece dildeki kelimeler ile ilgili bir konu değildir, tam tersine insan düşünsel süreçleri büyük oranda eğretilemelidir. Eğretileme, bir şey hakkında düşünmek için sağlam bir yol tanımlar (Lakoff ve Johnson 2003).

Eğretileme, bir kavramın oluşması için gerekli ortamı hazırlayan dilin, yapısı veya temeli olarak çalışır. Dil ile ilgili kavramlarda bir temel oluşturması gibi, marka veya ürün iletişimine de benzer bir etki yapabilme yetisi nedeniyle eğretilemeler, tasarımda da temel sağlayıcı olarak düşünülebilir. Eğretileme bir kavramı betimlemede güçlü bir dayanak olabildiği için, markanın iletisini anlatan ya da ona paralel olan bir eğretileme, iletişim için çok etkili bir yol olabilir. Eğretileme, kavram ya da marka için bir temel yapı taşı olarak belirlendikten sonra, ürünün asıl tasarım süreci, bu eğretileme çevresinde oluşturulan-seçilen tasarım biçim dili bileşenleri ile sağlanır. Eğer bir binanın yapısı eğretilemenin kendisi ise, tuğla ve harç da tasarım biçim dili bileşenleridir.

Eğretilemenin, sahip olduğu tasarım biçim dili bileşenleri ile gönderebileceği iletiler çeşitlidir. Eğretileme, geniş ölçüde bütün markayı anlatmak veya daha küçük ölçüde tek bir ürünün iletişim gereksinimlerini karşılamak için kullanılabilir. Marka kimliği, onu betimleyecek eğretilemeli bir kavram üzerinden aktarılabilir. Bu eğretilemeli kavram, markanın tüm ürünleri için ortak bir tasarım biçim dili oluşturulmasında kullanılır. Bu ortak tasarım biçim dili, bütün ürün ailesinin tutarlı bir ileti taşıması ve marka ailesi olarak tanınmasını sağlar.

Örneğin Clinique markası, firma için hedef kitleyi oluşturan kadınlar ve kendilerine özgü ihtiyaçlarını bilimsel bir yaklaşımla incelemekte olduklarını ürünlerde anlatmak için "saf bilim" eğretilemesini seçmiştir. Tüm ürünlerin tasarım biçim dili "saf bilim" eğretilemesinden doğmaktadır ve bu ortak dil sayesinde marka ürünlerinin bütünsel ve tutarlı bir ileti taşıması sağlanmaktadır. $\mathrm{Bu}$ eğretileme, Clinique markasını bilimsel bir laboratuvarın güvenilirliği ile ilişkilendirerek tüketici zihninde diğer 

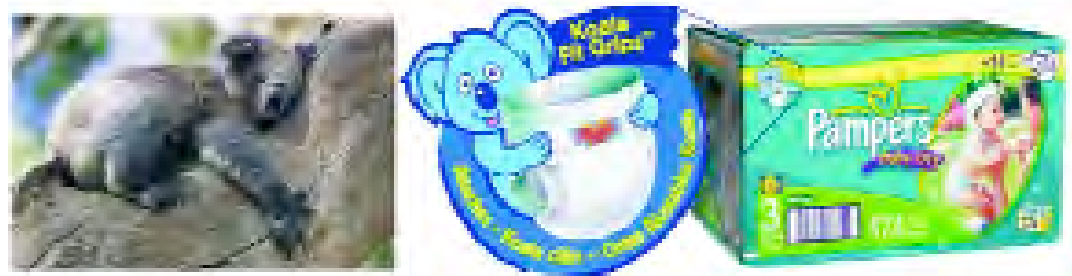

markalardan üstün ve farklı bir konum kazanmasını sağlamaktadır. "Saf bilim" eğretilemesini destekleyen tasarım biçim dili bileşenlerine örnek olarak periyodik tablodaki sembollere benzeyen bir "C" harfinden oluşan Clinique logosu, ürünlerin laboratuvar tüp ve şişelerini andırır basit ve işlevsel biçimleri ve bilimin geleneksel rengi olan gümüş renginin kullanıldığı ürün aksamları verilebilir. Tüm bu tasarım biçim dili bileşenleri, eğretilemenin bütünlüğünü korumakta ve Clinique'i bilinen ve kolayca ayırt edilebilen bir marka haline getirmektedir. (Şekil 7)

Eğretilemeler, uygun tasarım biçim dili bileşenlerinin kullanımı sayesinde, bir ürün üzerindeki farklı bir özelliği vurgulayabilirler. Yukarıdaki örnekte, bebek bezinin farklı yapıdaki sarma özelliği, koala eğretilemesi kullanılarak, "yumuşak ama sıkı koala sarılması" deyişi ile aktarılmaktadır. Etiketler üzerinde ürünün bebek bedenine mükemmel uyumunu iletebilmek için, ürünün bedeni sanki bir koalanın ağaç gövdesini tutuşu gibi sardığını betimleyen anlatımlar kullanılmıştır. Bu anlatım, kullanıcıya ürün ve ürünün bebekle ilişkisi hakkında hatırlaması kolay bir bağlantı sağlamaktadır. Bu tutum, paket etiketleri üzerinde ürünün bebek bedenine uygunluğunu anlatan basit bir iki cümle bulunmasından çok daha etkilidir. (Şekil 8)

Loreal'in çocuklar için ürettiği şampuanın şişe biçimini geliştiren tasarımcılar, hedef kullanıcılarını yani 7 yaş altı çocukları detaylı bir şekilde araştırmışlardır. Bu gruptaki çocukların çoğu yıkanmaktan, göz yakan temizlik ürünlerinden korkmaktadırlar. Yaşları gereği hayvanları merak etmekte ve onlar hakkında yeni şeyler öğrenmektedirler.

Çevrelerindeki dünya ile ilgili olarak sadece en temel atatipik simgeleri bilmekte, birçok şeyi onlar sayesinde anlamaya çalışmaktadırlar. Bu grup çocuklar renkli ve ilginç şekilli objelere
Şekil: 8

Pampers bebek bezlerinin farklı bir sargı sistemine sahip yeni ürünü için koala eğretilemesi.

sekil: 9

Loreal focuk şampuanı.
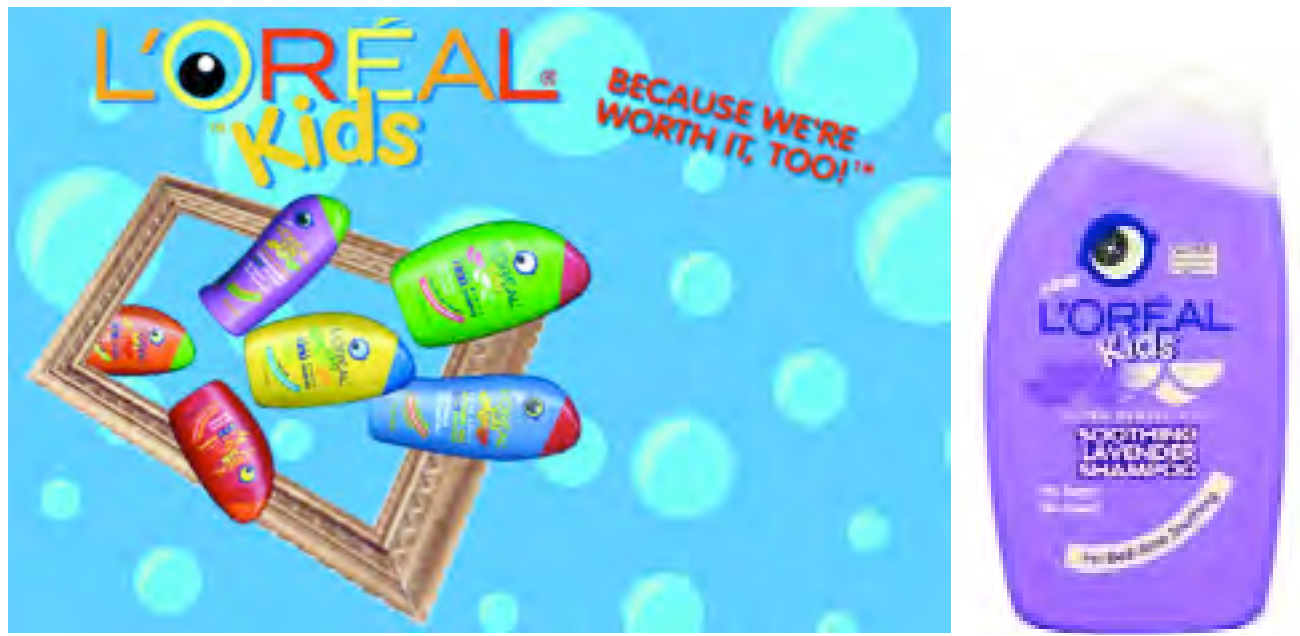

104 Sayı 8, Aralık 2009 

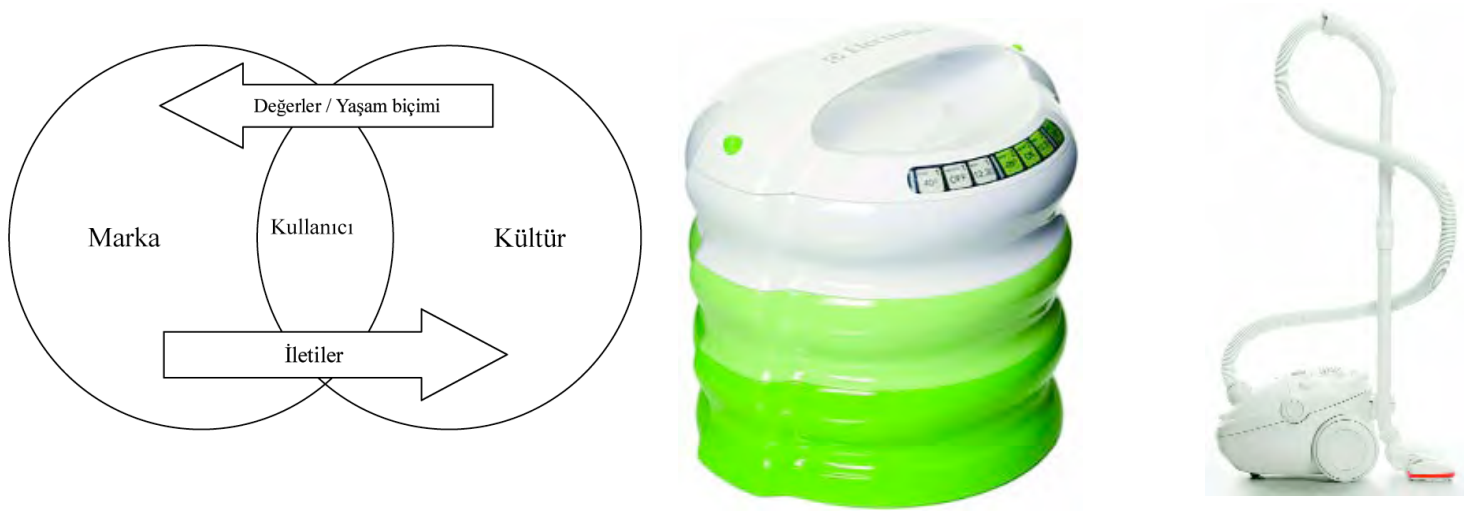

şekil: 10 her zaman ilgi duymaktadırlar. Bu kitleye

Marka, kültür ve kullanıcı arası ilişki.

Şekil: II Elektrolüks, Sefertas eğretilemeli yiyecek taşıma kabı Nevale (Türk Yemek Kültürü, Metin Kaplan, 2006) Ultra Silencer, elektrikli süpürgesi, "kar kadar sessiz" (Isvef Kültürü, Többi Tagja, 2005)

ulaşabilmek için, suda oyuncak haline getirilebilen bir hayvansal biçimin uygun olduğunu düşünen tasarımcılar, balık eğretilemesini seçmişlerdir. Balık atatipinin belirgin özellikleri oval şekil, yuvarlak hatlar, göz, kuyruk, yüzgeçler, solungaç ve pullardır. Yapılan tasarım çalışması sonucunda, üzerindeki göz şekli, balık pulu, solungaç grafikleri ve ağzın balıktaki yerine yaklaşık konumlanan kapak ile balık kafasına gönderme yapan renkli bir ürün ortaya çıkmıştır. Tasarımcılar balığa ait temel özelliklerden yüzgeç ve kuyruğu tasarım dışında bırakmış, solungaçları da değişikliğe uğratarak kullanmışlardır. Ürünün anlatmak istediği kavramlar, oyun, hayal gücü ve banyo zamanı eğlencesi olarak sınırlanmıştır. Eğretilemeli etkileşim temsîli düzeyden öteye götürülmemiş, çocukların hayalgücüne de serbest alan bırakılmıştır.

Bu eğretilemeli yorum ile, oyuncak benzeri kimlik kazandırılan ürünün, çocuk kullanıcı gözündeki oyun değeri sayesinde rakipleri arasında öne çıkması amaçlanmıştır. Oyuncak kimliğiyle bebeğin banyoya duyacağ arttırabilecek bir ürünün, ebeveynler tarafından da tercih edileceği unutulmamıştır. (Şekil 9)
Eğretileme kavram aracı, tasarım biçim dili oluşturmaya yardımcı zengin kaynakları sayesinde, tasarımcıya marka iletisinin ürün ailesine ve ürüne ait özelliklerin de alıcı ortama kolayca aktarılmasını sağlayacak tasarım özelliklerini oluşturmada yardımcı olabilmektedir.

Eğretileme, kullanımının esnekliğgi sayesinde tasarımcının etkileșim ihtiyaçlarını karşılamaya yönelik güçlü bir araç haline gelmektedir.

\section{Ĕgretileme - Kültür}

Küresel pazar, dünya üzerindeki çok farklı kültürlerin değişik kuvvetlerdeki etkilerinin birleşiminden ortaya çıkan popüler trendlere sahiptir. Tasarımcıların, ürünlerinde kullanacakları biçim dilini geliştirirken, bu trend ve akımları izlemeleri, Amerikan ve benzeri güçlü pazarların dikte ettirdiği stereotipik bazı ürün özelliklerini aşırı vurgulayarak ürünlerinin alelade ürünler haline gelmesine izin vermemeleri gerekmektedir. Tasarımcı, geliştirdiği ürünün bazı özelliklerinin, hedef kitleyle külttürel uyumsuzluklar yaratmasından şüphelendiğinde, kitlenin yaşadığı ülke külttürünü, kitlenin kendi özelliklerini daha detaylı incelemeli ve tasarım kararlarını buna göre gözden geçirmelidir.

(Şekil 10-11) 
Ürün tasarımında kullanılmak üzere kültüre dayalı bir eğretilemeli kavram seçildiğinde, tasarımcı soyut düzlemler arası geçiş için, eğretilemeli kavramı çeşitli alt karakterlerine ve temsil eden sembollerine genişletir. Örneğin "Türk çay kültürü̈"nün birden fazla alt karakter ve sembole sahip görselleri bize kazandırdı ğ görülür; "İki katlı çaydanlık-demlik",

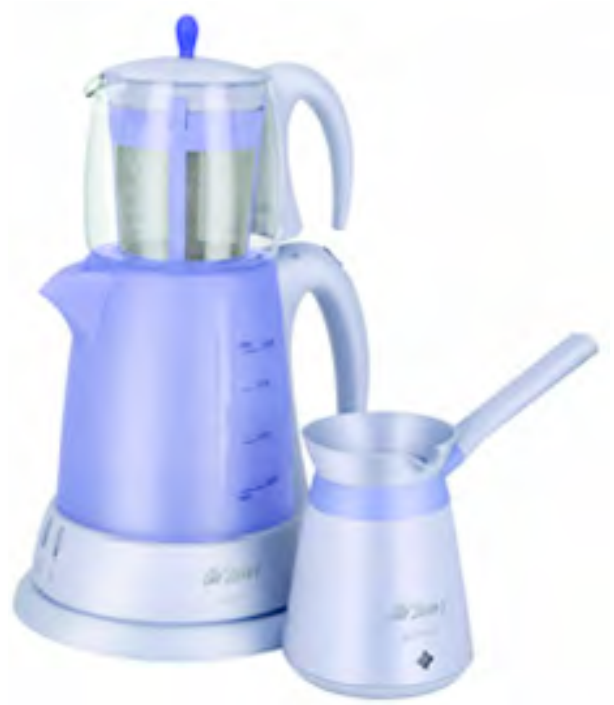

“dantelli çaydanlık örtüleri”, "ince belli bardak”, "çay karıştırma hareketi”, “çay sohbeti”, “çay keyfi” gibi. Tek başlarına çok anlamlı olmayan bu kavramlar, bir araya geldiklerinde köklü ve derin bir kültürü, "Türk çay kültürü"nü ortaya çıkartır. Tasarımcı bu görselleri, ürünün genel veya alt parçalarının (düğmeler, ekran, işletim sistem arayüzü vs.) tasarım biçim dilini oluştururken kullanabilir. Arzum'un çay-kahve makinası, bir uygulama Marka kültür iletiler - değerler / Yaşam biçimi kullanıcı örneği olarak gösterilebilir. Tasarımcilar yeni ürün grubunu, geleneklerine bağlı Türk toplumunun hemen algılayıp benimsemesi ve kolayca kullanabilmesi amacıyla çaydanlık ve cezve eğretilemelerini kullanarak gerçekleştirmişlerdir. (Şekil 12)

Tasarımın bir öyküsünün olması, ürünü zenginleştirici bir özelliktir. Bilinen bir kültürel hikayenin ya da masalın karakterleri, eski, kırsal, kentsel ve bunun gibi hikayeye ait yaşam tarzlarını aktarmada kullanılabilir. Ürünün geleneksel bir öyküye dayanması, bu öykünün taşıdığı birçok özelliğin, bazen öyküye ait tek bir ögenin içerilmesi ile ürüne kazandırılması anlamını taşıyabilir.

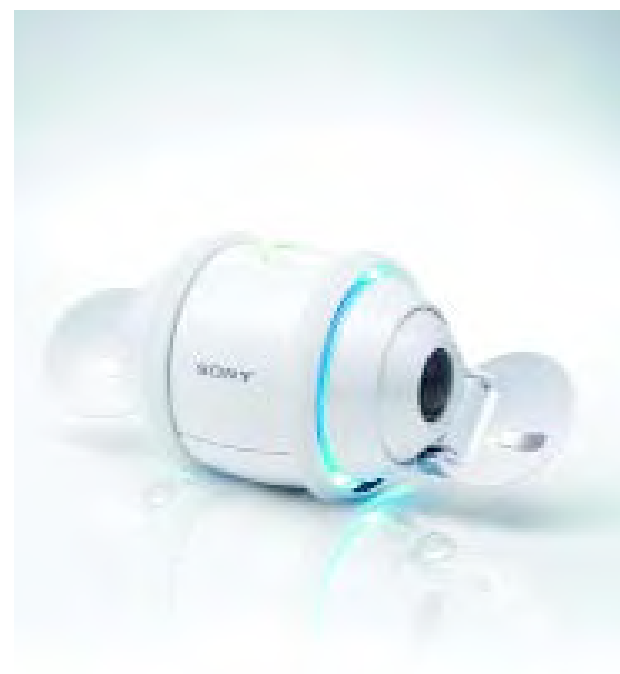

Eğretileme ürünlerde yönelim belirlenmesinde kullanılabilir; alfabesi soldan sağa doğru okunan batı kültüründen insanlar için sol geri, sağ ise ileri anlamı taşır ve bu eğretilemeler günlük hayatta da sıklıkla kullanılır. Cep telefonu ve müzik çalıcı cihazlar gibi birçok üründe de bu tip eğretilemeler kullanılagelmektedir. Yönelimsel eğretilemeyedayalı bu uygulamalar, kullanıcıların ürünü araştırıp taşıdığ 1 özellik ve işlevleri keşfetmesi aşamasında çok önemlidir. Zihinlerinde hazır olan, hayatlarında kullanmaya ve görmeye alışkın oldukları yön kavramlarını, üründe de bulan kullanıcının, o ürüne uyum sağlamasının daha kolay gerçekleşmesi beklenebilir. Ürünün taşıdığı yönsel bilgilerin algılanabilmesi için, uygulanan yönsel eğretilemelerin, kullanıcının
Şekil: 12

Arzum cay ve kahve makinasi

(www.arzum.com.tr).

Sekil: 13

Sony Rolly. 
Şekil: 14 Alessandro Mendini: Anna G. Sişe

Şekil: is

Üst sira:

Stefaton Giovannoni: Merdolino tuvalet firçasi (Alessi, 1993)

Stefaton Giovannoni: Bombo masa (Alessi, 1998)

Phillippe Starck:

Limon sıkacă̆

(Alessi, 1990)

Alt sira:

Sori Yanagi: Kelebek Sandalye (Yanagi, 1954),

Eero Saarinen: Lale Sandalye, (Saarinen, 1957),

Stefano Giovannoni, Ahtapot Saat (seiko 1997) tıpası af̧ıcı (Alessi, 1994).

zihnindeki yönsel bilgilerle eşleşebilmesi gereklidir.

Sony ürünü Rolly robotik mp3 çalıcısı, kabuğu içerisinde bulunan yer çekimi algılayıcıları sayesinde duruş yönünü bilmekte ve buna göre ses açma kapama, kanal değiştirme düğmelerinin işlevlerini zihindeki "üst artış, alt azaltma" yönsel bilgisine de göre otomatik ayarlamaktadır. Yani ürün ne konumda tutulursa tutulsun, üstte kalan ayar düğmesi arttırma, altta kalan ayar düğmesi azaltma işlevi görmektedir. (Şekil 13)

Eğretileme, makina ve hareketsiz varlıklara insan karakterine uygun yetenekler kazandırarak onları daha

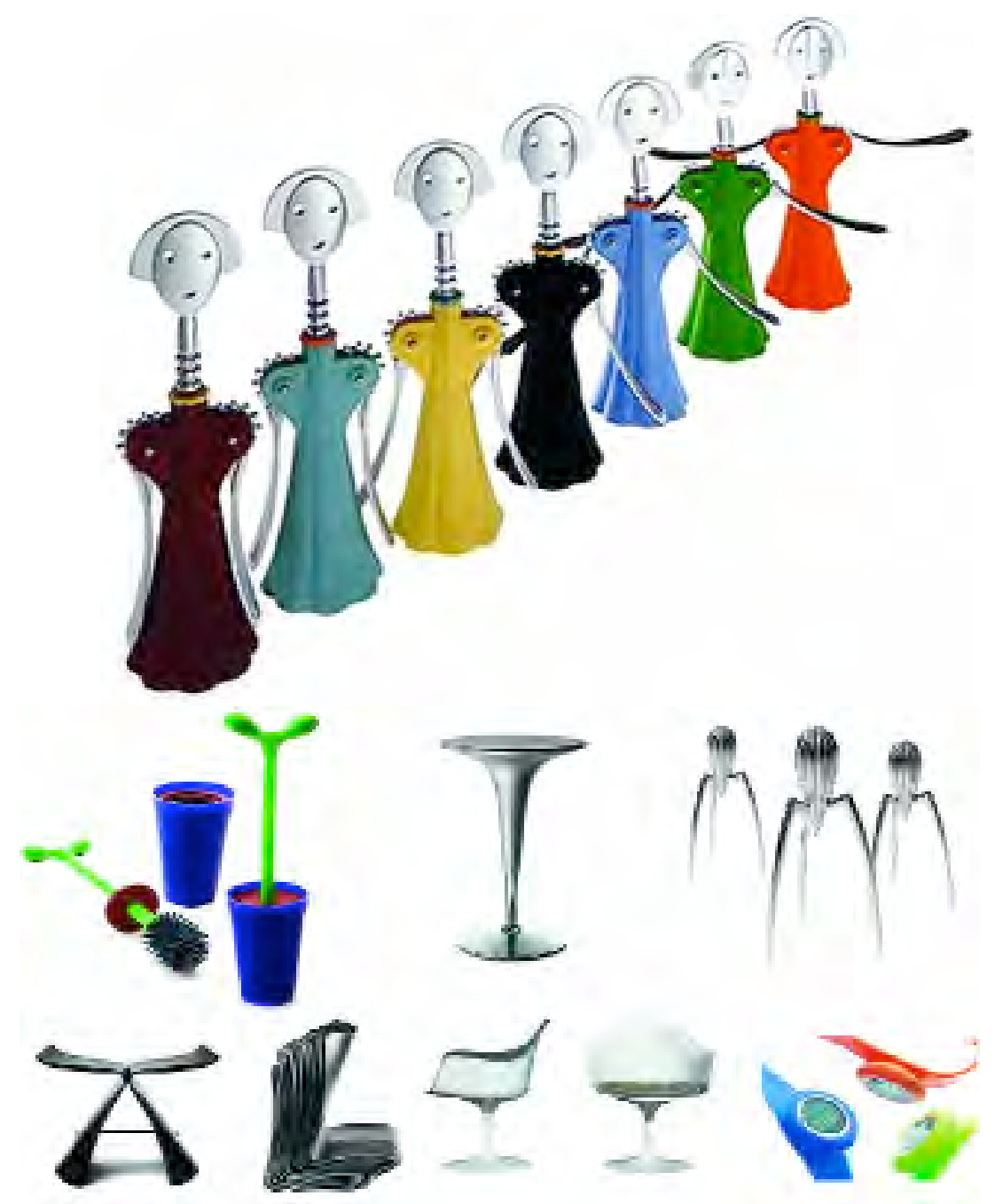

yaklaşılır - kullanılır hale getirme yetisine sahiptir. Lakoff ve Johnson'a göre eğretileme, "dünya üzerindeki olgulara, kendi amaçlarımız, değerlerimiz, hareket ve karakteristiklerimiz temelinde anlayabileceğimiz insani biçimlerle anlam verebilmemizi sağlar" (Lakoff ve Johnson, 1980).

Eğretileme, üründeki karmaşık işlemleri, daha basit insancil eylemler cinsinden ortaya koymak amaçlı kişiselleştirmeler oluşturulmasında da kullanılmaktadır. Eğretileme kullanarak bu işlemleri kişiselleştirebildiğimizde bunların üründeki mekâniğini daha iyi anlayabiliriz.

Kişiselleştirme yaklaşımı, ürünlerin kişiler yerine insan dışı doğal varlıklar, hayvanlar, bitkiler vs.'ye benzetilmesiyle de uygulanabilir. Doğanın düzenli biçim ve özellikleri araştırılarak seçilenler, ürünlerin tasarımında biçim dili bileşenlerini oluşturmada kullanılır. (Şekil 14-15)

Eğretilemenin ana işlevi bilinmeyeni bilinenler cinsinden göstermek ve anlatmak olduğuna göre, benzer şekilde tanınan kavramlardan faydalanarak yeni kavramları kullanıcıya tanıtmada da kullanılabilir, algılamada önemli gelişmeler sağlayabilir. Bilgisayarlardaki masaüstü kullanıcı ara birimi ve internet tarayıcısı kavramlarının tanıtılmasında sağladığı fayda buna iyi bir örnektir. Eğer tasarımcılar tanıtmaya çalıştıkları kavramla ilgili kendi eğretileme önerilerini ortaya atmazlarsa, kullanıcılar yanlış eğretilemeler üreterek kullanmaya başlayacak, bunlar da tasarımcının ürün ile ilgili olarak aklından geçen amaçlarla uyumsuz ya da onları anlatmada yetersiz olabilecektir. Uygun eğretilemelerin kullanıcılara önerilmesi, tasarımcının önemli sorumluluklarındandır. Yerinde 
kullanılmayan eğretileme, kullanıcıları aydınlatılmak istenen konuya daha ulaşamadan eğretilemenin alt ögeleri içinde hapseder. Bu da kullanıcıda ürünü algılayamamaya bağlı memnuniyetsizlik, kafa karışıklığı ve ürünün yönelik olduğu alana bağlı olarak çok daha olumsuz sonuçlar yaratabilir.

\section{Tasarım süreçlerinde ĕgretileme}

Tasarımcılar eğretilemeyi projelerinde itme gücü olarak kullanabilir, eğretilemeli teknikler sayesinde yeni etkileşimler veya etkileşim tarzları yaratabilirler.

Eğretileme, planlanan yeni bir çalışma tarzının merkezini oluşturabilir. Tasarım sürecindeki temel gereklerden biri olan kavramsal çerçevenin oluşturulmasında eğretileme önemli rol oynayabilir.

Eğretileme günlük yaşam süreçlerimizin genellikle farkında olmadığımız bir parçasıdır ve bir araç olarak tasarım da dahil olmak üzere çeşitli iş süreçlerinde kullanılabilir.

Eğretilemeli kavramsal bir çerçeve, ürün ve hizmetlerin yeniden türetilmesinde ilk problem tanımından teslime kadar her aşamanın tutarlı şekilde oluşturulabilmesinde fayda sağlayabilir.

Tasarımcılar, üzerinde çalıştıkları ürünlere ait sorunları çözümlemek için, uygun eğretileme ile yeniden tanımlamalar gerçekleştirebilirler. Bu tanımlamalar, üründe yeni fark edilen bir sorun için veya ürünün bir önceki modelinden beri belli sorunlar için kullanılabilir.

Tasarımcı olmanın zorlu yanlarından biri de tanıdık olmayan alanlarda çalışmaktır. Tasarım grupları, sıklıkla hakkında çok az bilgi sahibi oldukları alanlarda çalışmaya yönlendirilirler. Yabancı alanlarda çalışabilmenin yolu ise o alanda uzman olan kişilerin yardımından faydalanmaktır. Farklı disiplinlerde uzmanlaşmış kişilerle anlaşabilme gerekliliği, beraberinde kendi sorunlarını getirir; sahip olduğu bilgi birikimi sayesinde uzman kişiye çok açık gelen konular tasarımcı için hâlâ kolay anlaşılır değildir. Bu sorunu aşmak için uygun bir yöntem, karşılıklı ekiplerin, ortak sorunları anlayabilmek için eğretileme kullanmasıdır. Eğretileme, doğası gereği alışık olunmayan konuların daha anlaşılır konularla eşleştirilmesinde kullanıldığı için, daha fazla ve detaylı açıklanması gereken herhangi bir olgu için de işe koşulabileceği rahatlıkla söylenebilir (Shank ve Gleber, 2002). Tasarımcılar, bildik bir alanın yabancı bir alanla olan ortak ve farklı özelliklerini bulmak için bilinen alanın karakteristik özelliklerinden faydalanabilirler.

Yeni fikirler, çeşitli fikirlerin bir arada yan yana bulunduğu durumlarda daha çok ortaya çıkmaktadır (Koestler, 1964). Fark yaratabilecek fikirlerin en yoğun şekilde ortaya çıkışı, tasarımcıların grup halinde çalışması durumunda meydana gelmektedir. Eğretileme bu tür ortamlarda bir beyin fırtınası yöntemi olarak kullanılabilir.

Böylece tasarımcılar çabukluk ve tam bir fikir birlikteliği ile yeni fikirler yaratabilirler. Aslında eğretileme, bir tür yan yana koyma işlemidir; iki farklı varlığın bir araya konarak birbirlerinin farklı karakteristiklerini açığa çıkarttı̆̆ yapılardır. Problemin ait olduğu alana ait eğretilemelerin bulunarak

kullanılması hem tasarımcılar arasında anlaşmanın daha iyi sağlanmasına hem de problemlerin daha kolay çözümlenmesine olanak verir. Tasarımcıların, bilinen kullanıcı problemlerine yoğunlaşmaları, bu problemli noktaları çözebilmek için aynı karakteristik özelliklere sahip gerçek dünya olay, varlık ve kavramlarını eğretilemeli olarak kullanmaları gereklidir (Erickson, 1989). Rastgele bile olsa her eğretileme, bir ürün hakkında farklı düşünce yolları ortaya çıkmasını ya da bir 


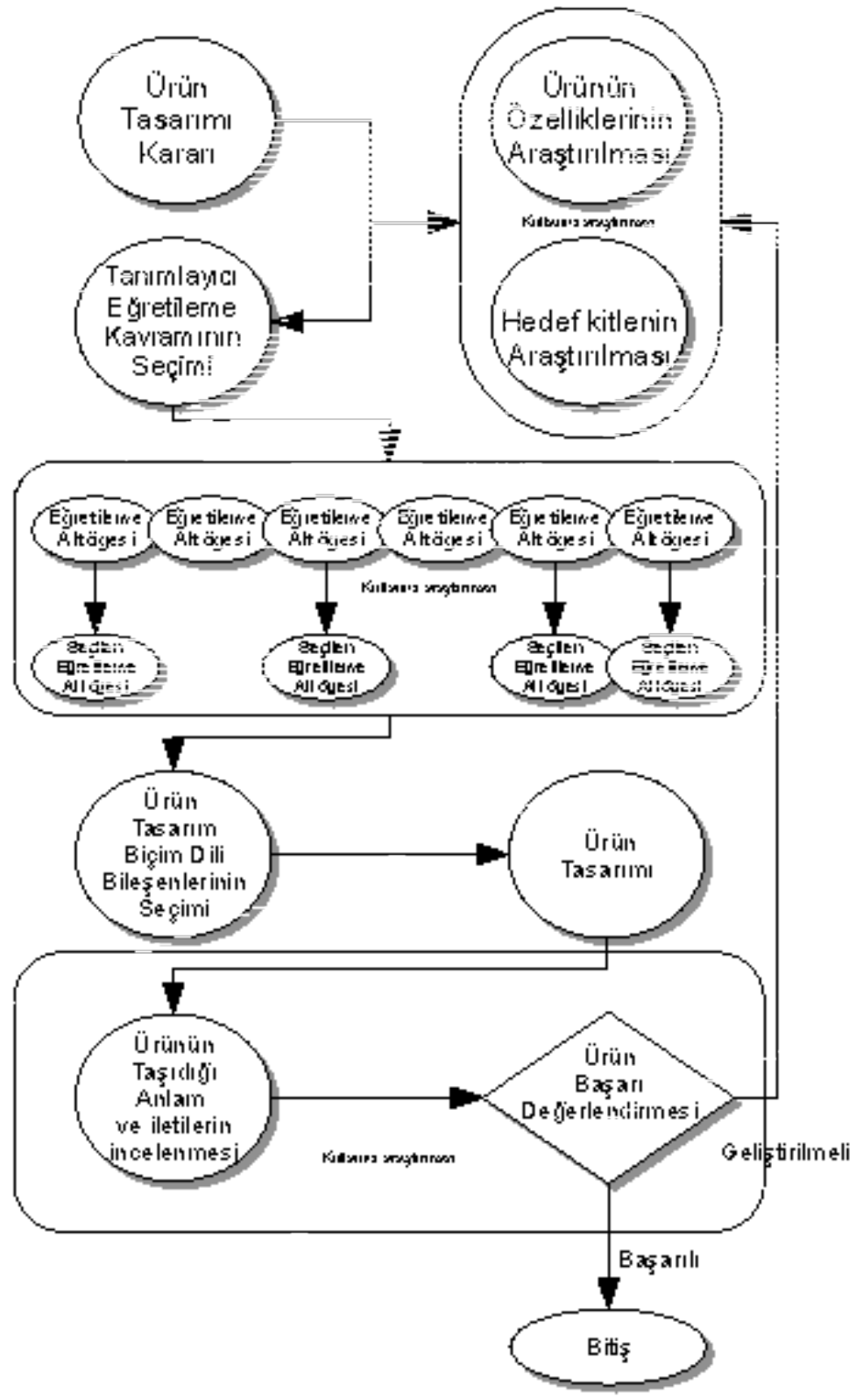

Şekil: 16 Endüstri tasarımında eğretileme kullanım yöntemi

basitleştirilmiş akıs şeması. tasarım sorunu için yeni çözümlerin bulunmasını tetikleyebilir.

\section{Endüstri Tasarımında Ĕgretileme}

Kullanımına Yönelik Yöntemsel Yaklaşımlar

Endüstri tasarımında eğretileme kullanımını yöntemsel hale getirmeye yönelik literatürde fazla sayıda çalışma olmadı̆̆ 1 görülmektedir.

Kristin LoWer Gautvik (2001), Zheng,
Mei-Yu (2003), Leong (2003) ve Kristen Rosenweigh'in (2007) endüstri ürün tasarımına uyarlanabilir nitelikte çeşitli çalışmalar gerçekleştirmişlerdir. Tez çalışmamız sürecinde, daha önce yapılmış araştırmalarda ortaya çıkartılmış bu yöntemler incelenmiş ve makina uygulamalarına daha fazla uyarlanabilirlik sağlanabilmesi amacıyla algoritma haline dönüştürülmeye çalışılmıştır. (Şekil 16-17) Yöntemlere ait süreçler, bilişim sistemlerince yürütülebilecek kadar basit alt adımlara ayırılmaya çalışılmıştır.

\section{Yöntemin Adımları}

1. Ürün araştırması gerçekleştir, ürün özelliklerini ve rakip ürünleri araştır.

2. Kullanıcı, hedef kitle araştırması gerçekleştir. Tasarımın oluşturulmasında önem taşıyan özellikleri listele, kültürel hikayeleri, tabuları vs. dikkate al.

3. Özellikleri yatayda görsel, işitsel, tatsal, kokusal, dokusal, davranışsal, dilbilimsel, kültürel kategorilere ayırarak sınıflandır.

4. Özellikleri dikeyde maddesel, duygusal ve saf beyinsel olmak üzere beynin üç bölümüne ait seviyelere göre sınıflandır. 5. Önceki bölümlerde elde edilen bilgiler doğrultusunda eğretilemeye giden ipuçlarını listele ve sınıflandır.

6. Bu bilgiler doğrultusunda, kullanıcılarla araştırma iletişimini sürdürerek amaca uygun eğretilemeli bir kavram belirle. 7. Belirlenen eğretilemeli kavramı, kullanıcı araştırmaları yardımıyla incele, kullanıcı üzerinde sına.

8. Bu eğretilemeli kavramın sahip olduğu, alt ögeleri ortaya çıkart, listele, sınıflandır. 9. Eğretilemeli kavramın alt ögelerinden, tasarlanacak ürünle doğrudan ilgili olanları seç.

10. Seçilen eğretileme alt ögelerinden, hedef kullanıcı kitlesi için en anlamlı olanları, tekrar kullanıcı araştırması yolu ile ayrışır. 
11. Listelenen eğretilemeli kavram alt ögelerinden hangilerinin ürün tasarımına uygulanacağına karar ver.

12. Seçilen ögeleri, ürünün biçimi, senaryosu, kimliği, malzemesi, öyküsü, rengi vs. gibi özelliklerinin ortaya çıkartılmasında kullan.

13. Ürün tasarımının maketini yaparak kullanıcı araştırması yolu ile başarı ihtimalini araştır.

14. Kullanıcı araştırmalarında, maket özelliklerinin, beklentileri karşılayamayacağına dair bir olasılık görünüyorsa önceki aşamalara dönerek tasarım araştırmasını ve buna bağlı olarak yapılan tasarım çalışmasını güncelle. $\mathrm{Bu}$ güncellemeyi olumlu sonuç elde edene kadar tekrarla.

15. Prototip üretimi gerçekleştir ve bir önceki adımdaki gibi kullanıcı araştırmaları yolu ile sına.

16. Kullanıcı araştırmalarında, prototip özelliklerinin, beklentileri karşılayamayacağına dair bir olasılık görünüyorsa önceki aşamalara dönerek tasarım araştırmasını ve buna bağlı olarak yapılan tasarım çalışmasını güncelle. Bu güncellemeyi olumlu sonuç elde edene kadar tekrarla.

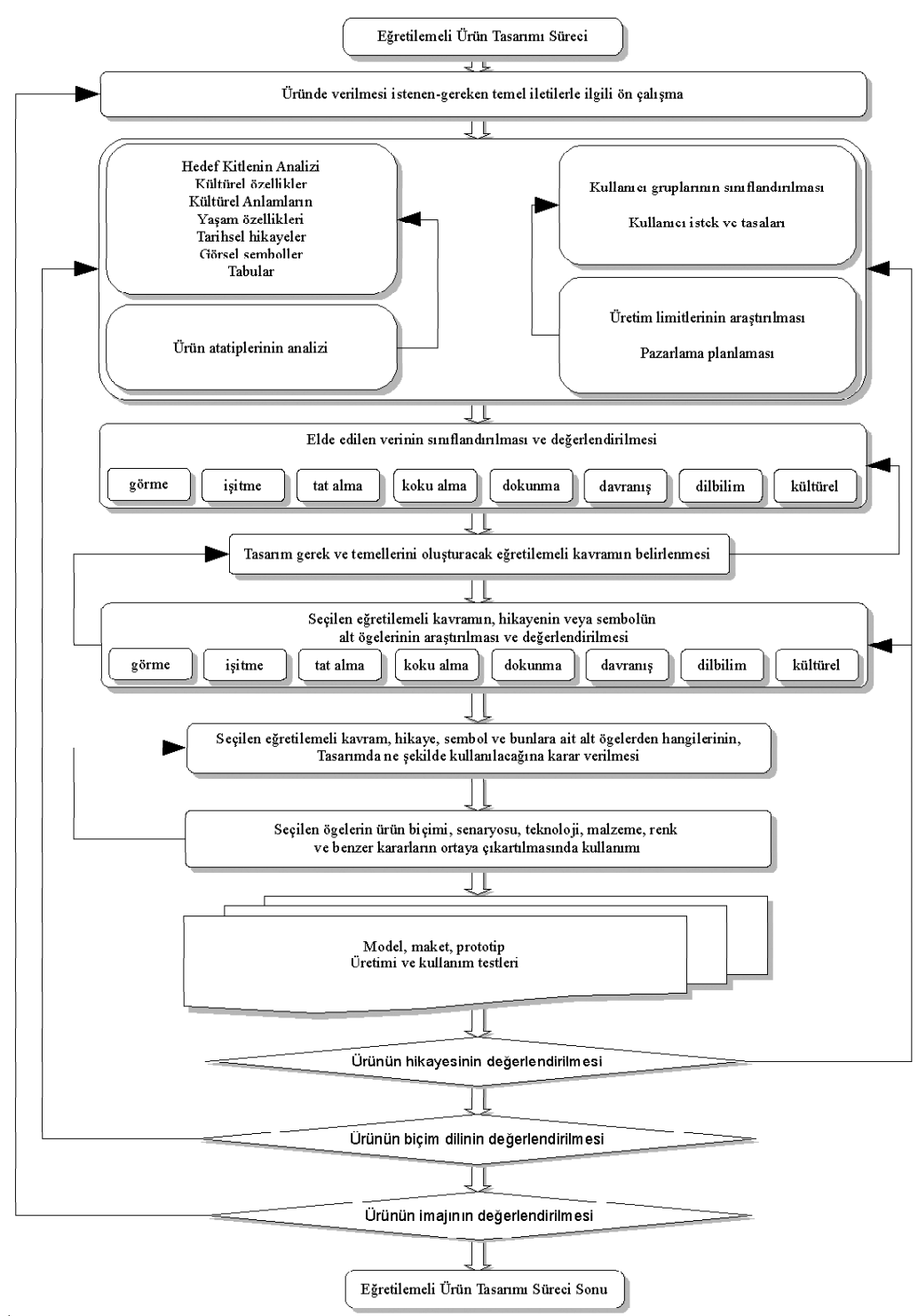

Şekil: 17

Eğretilemeli ürün

tasarımı süreci

akıs diyagramı.

110 Sayı 8, Aralık 2009 
17. Pilot üretim gerçekleştirerek, hedef kitleyi temsil eden küçük bir kitleye satışını gerçekleştir.

18. Bu kitlenin pilot ürünle ilgili görüşlerine başvur. Kitle görüşleri, ürün başarısı ile ilgili olumsuz durumların ipuçlarını veriyorsa, bu görüşleri detaylı şekilde incele ve üründeki olası hataları belirle.

19. Hataları düzelterek tekrar maket, prototip veya pilot üretim aşamalarına dön. Kitle görüşündeki olumsuzluklar ortadan kalkana kadar düzeltmeli kontrollere devam et.

20. Ürün tasarımı ortaya çıkmış, özellikleri kullanıcı onayı ile sınanmıştır. Seri üretimle ilgili son düzeltmeleri gerçekleştir. Seri üretime geçilebilir kararını ver. Süreç tamamlanmıştır.

Şekil: 18

Tasarım sürecinin Ürün tasarımında eğretilemenin kullanımı

izlenmesi ve ile ilgili bu akış şemasının doğru

değerlendirilmesi

amaşl

kontrol aygiti. uygulanıp uygulanmadığının

değerlendirilmesi, "eğretilemeli ürün

\section{Eğretilemeli Ürün Tasarımı İçin Süreç Kontrol Aygıtı}

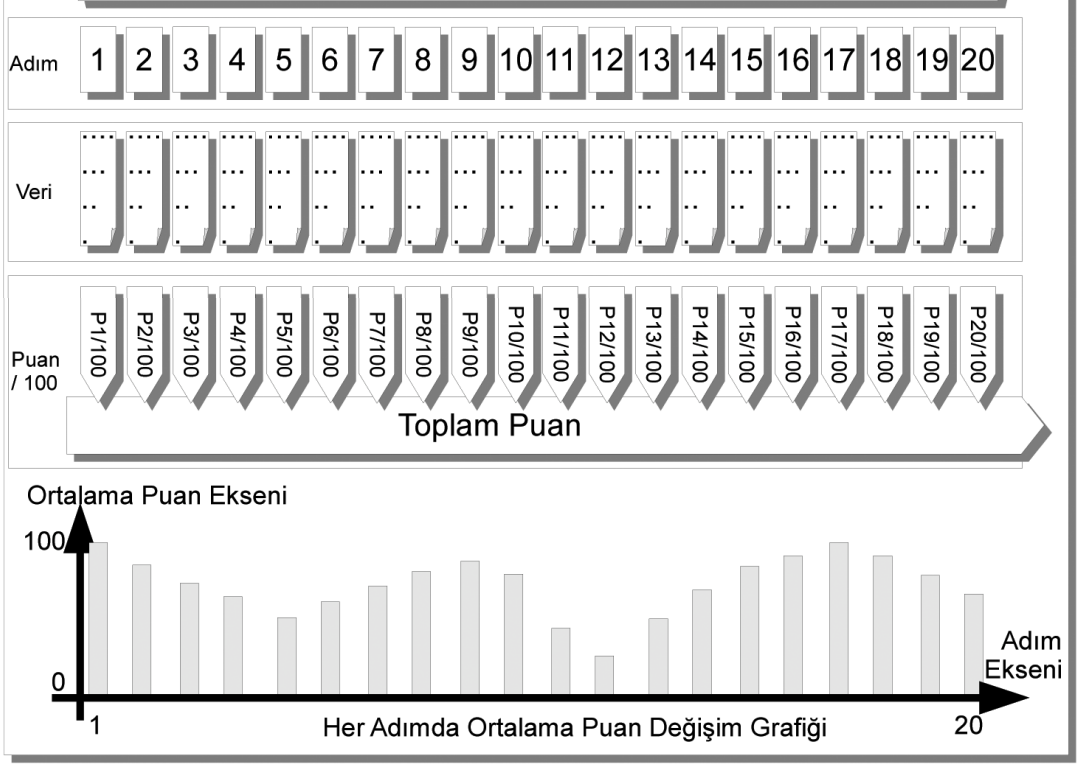

tasarımı için süreç kontrol aygıtı" ile gerçekleştirilecektir. (Şekil 18) Bu araç, tasarım sürecinin adım adım izlenebilmesi ve puanlanarak değerlendirilmesi amaciyla tasarlanmıştır.

Her adımın uygulanmasıyla elde edilen veri, aygittaki tablonun ait olduğu veri kutucuklarına yerleştirilir ve o adımın başarılma düzeyi, tasarımcı tarafından 100 üzerinden puanlanır. Puanlamanın kolaylaştırılabilmesi için yöntemin 20 adımı, alt basamaklara ayrılmıştır. Basamakların ne seviyede gerçekleştirildiği ve işlem sonucu elde edilen done sayısına bağlı olarak puanlama yapılır. Sonuçta tüm adımlar için bir toplam puan elde edilir.

Puan, tüm adımların \%100 başarıyla gerçekleştirilmiş olma durumunda 2000'dir. Bu şekilde ortaya çıkan sayısal başarım değeri ile tasarımda kullanılabilecek çeşitli eğretileme kavramları ve tasarım süreçlerinin yetkinliği hakkında fikir elde edilebilir, bunlar birbirleriyle nicelik karşılaştırmalarına tabi tutulabilir. A tasarım süreci, B tasarım sürecinden $\% 23$ daha başarılıdır ya da P eğretilemeli kavramının yetkinliği $\mathrm{Q}$ eğretilemeli kavramının yetkinliğinden $\% 12$ daha düşüktür gibi, sayısal değerlendirmeler yapılabilir. Puanın en üst değerden belirli bir oran altına kadar olduğu değerler, tasarım ve eğretilemenin kullanımı açısından başarılı kabul edilebilir. Örneğin başarı limiti \%15 ise, $2000-(0.15 \times 2000)=1700$ 'den düşük puan alan tasarım süreçleri, tekrar değerlendirilecektir şeklinde bir karar alınabilir.

Eğretilemenin, tasarımda bir kavramsal araç olarak kullanımı, bu tezde detayları açıklanan endüstri ürün tasarımı süreci etrafında kurallar temeline oturtulmaya 
çalışılmıştır. Tasarım süreci, açık olarak ifade edilen yirmi ayrı adımla tanımlanmıştır. Sürecin işleyişinde, tasarımcının sahip olduğu yaratım, karar, biçim inisiyatiflerine dokunulmamış, ürününü özgürce ve istediği gibi ortaya çıkartma olanağı korunmuştur. Böylece tasarım sürecinin, özündeki serbestçe yaratım değerini kaybetmeden daha belirgin adımlarla gerçekleştirilmesi, daha yakından izlenebilmesi ve değerlendirilebilmesi sağlanmıştır. Sürecin değerlendirilebilmesi için bir süreç kontrol aygıtı tanımlanmıştır.

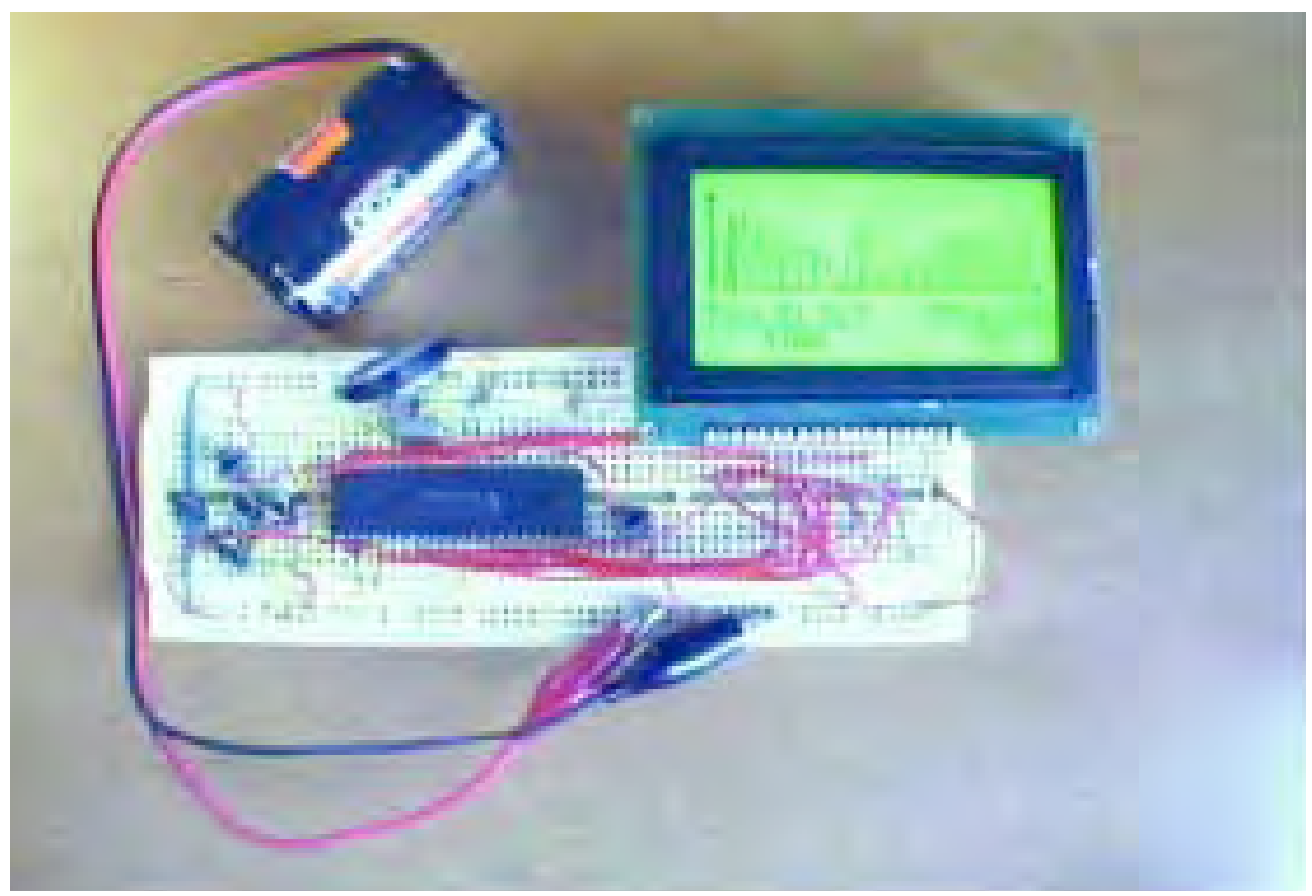

Şekil: 19

Endüstri tasarımı

süreç kontrol

mikrobilgisayar1.

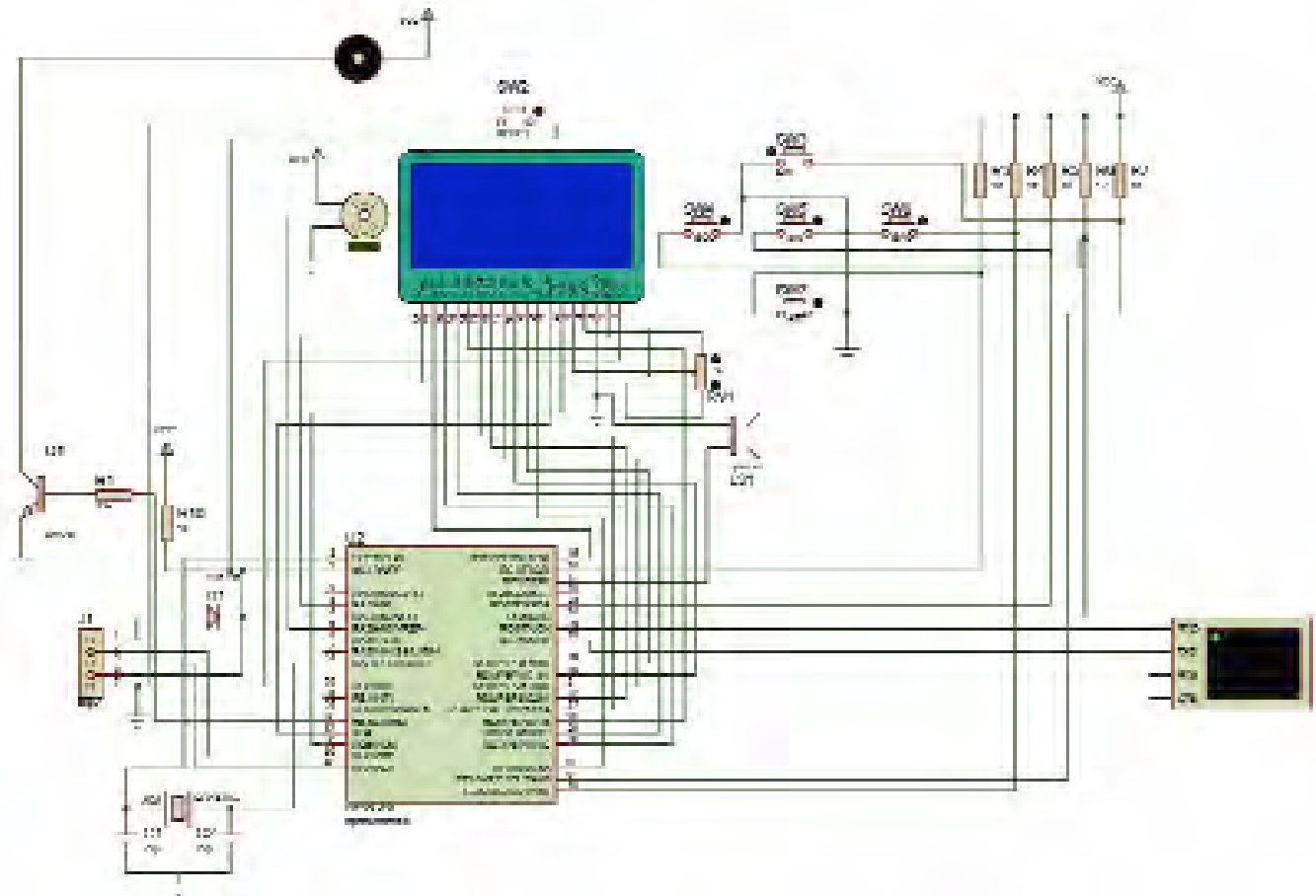


Aygıtın çalışmasını sağlayacak detaylar açıklanarak, gerçekleştirilmesinin ve kullanımının mümkün olduğunca kolaylaştırılması sağlanmıştır. Bu amaçla yirmi kullanım adımı, daha alt seviyelere bölünerek, bilgisayar benzeri hesaplama ortamlarına uygulanabilir hale getirilmiştir. Endüstri ürün tasarımı için süreç kontrol aygıtı, bir bilgisayar programı, aktif bir web sayfası ya da kendi başına çalışan, bağımsız bir elektronik devre biçiminde gerçekleştirilebilir.

Aygıtın gerçekleştirilebilirliğinin gösterilebilmesi için, bu bölümde anlatılan yirmi adımlı tasarım süreci ve puanlama aygıtı elektronik bir cihaz olarak tasarlanarak, gerçek elektronik parçalar ile gerçekleştirilmiş, çalıştırılmıştır. Cihaz, sıvı kristal ekranlı, bünyesindeki $\mathrm{C}$ programlama dilinde yazılmış algoritmayı çalıştıran bağımsız çalışabilir bir mikrobilgisayardır. Mikrobilgisayar, Microchip firmasının ürünü PIC 18F458 serisi mikroişlemci kullanılarak gerçekleştirilmiştir. Tasarım yöntemi adımlarını ve gerekli değişkenleri depolamak için, mikroişlemcinin 1536 bytelık rastgele erişimli belleğinin \%95'i kullanılmaktadır.

Algoritmayı gerçeklemek için yazılmış C kodu, mikroişlemcinin 32Kbyte'lık flash belleğinin \%47'sini kaplamaktadır.

Mikroişlemci 8Mhz frekansında çalışarak, saniyede yaklaşık 8 milyon komut yürütmektedir. Mikrobilgisayarın ürün-kullanıcı arayüzü olarak 128x64 nokta sayısına sahip arkadan aydınlatmalı grafik LCD ekran ve bilgi girişi amacıyla da beş tuş kullanılmaktadır. Bu tuşlardan ikisi adımlar arası geçişi sağlamakta, ikisi puan girişini sağlamakta, biri ise puanlama kipinden, rapor kipine geçilmesini sağlamaktadır.

Rapor kipinde, girilen puanlara göre sis- tem başarı puanları mikrobilgisayar tarafından hesaplanmakta, ekrana çizilen adımların başarı eğrisi ile birlikte kullanıcıya sunulmaktadır. Mikrobilgisayarın elektronik devresi şekilde sunulmuştur (Şekil 19). Tasarım araştırması süreci, buna bağlı olarak planlanan "endüstri ürün tasarımı için süreç kontrol aygıtı" ve aygıtın sağlaması olan elektronik mikrobilgisayar uygulamasının, geliştirmeye açık ve başka ortamlara aktarılarak tasarımcının kullanımına sunulabilir olduğu düşünülmektedir. Süreç ve aygıt endüstri ürünleri tasarımında eğretilemeli anlatımların, yöntemli kullanımına olumlu katkı sağlayacaktır 


\section{KAYNAKÇA}

A.I.A. Costa, D. Schoolmeester, M. Dekker ve W.M.F. Jongen. 2003. Exploring the Use of Consumer Collages in Product Design. Product Design \& Quality Management.Wageningen University.

Appleton. Bloch, Peter H., Brunel, Frederic F., and Arnold Todd J. 2003. "Individual Differences in the Centrality of Visual Product Aesthetics: Concept and Measurement". Journal of Consumer Research. 29 (March), $551-65$.

Aubry, D. and Vavik, T. 1992: Produktdesign, Barthes, Roland ([1970] 1988). The Old Rhetoric: An Aide-Memoire. In The Semiotic Challenge trans. Richard Howard.

Bayrakçı, O. 2004. Çă̆daş İletişim Kuramları Açısından Tasarımda İletisimsel Modeller. Mimar Sinan Üniversitesi.

Butter, Reinhart. 1993. "Where Meanings Escape Functions," Design Management Journal. 4(2), 30-37. 'Design Is Making Sense (of Things)'," Design Issues, 5(2), 9-39.

Butter, Reinhart. 1984. "Exploring the Symbolic Qualities of Form" Innovation. 3(2): 4-9.

Carl-Gustaf Lundholm. 2003. The Use of Metaphors in Product Design. Department of Product Design. Norwegian University of Science and Technology.

Dan Saffer. 2005. The Role of Metaphor in Interaction Design. The School of Design. Carnegie Mellon University.

Dumas, A. 1999. Building totems: Metaphormaking in Prod uct Development. Design Management Journal. Winter.

Dumas, Angela. Winter 1994. Building Totems: MetaphorMaking in Product Development. Design Management Journal. 71-82.

Feldman, Jerome A. 2006. From Molecule to Metaphor. A Neural Theory of Language. The Massachusetts. MIT Press.

Fouro boros, 2009. Brain, Metaphor, Archetype, Brand http://www.alchemysite.com/blog/brain_brand_01.html

Fu-Yuan, Li, 2005. Made in Taiwan: Using Metaphor as a Design Strategy.

Gregan-Paxton, Jennifer and Roedder John, Deborah. 1997 Consumer Learning by Analogy: A model of Internal Knowledge Transfer. Journal of Consumer Research. 24 (December): 266-84.

Holbrook, Morris B. and Hirschman, Elizabeth C. 1982. The Experiential Aspects of Consumption. Journal of Consumer Research. 9 (September): $132-140$

Hong Cheng. 2006. The Study of Cultural Interface in Taiwan Aboriginal Twin-Cup. Postgraduate School of Industrial Design. Chang Gung University.

Kawama, Tetsuo 1990. A Semiotic Approach to Product Forms. In The Semiotic Web.

Krippendorff, Butter. 1984. Product Semantics: Exploring the symbolic qualities of form.Innovation. vol 3 no 2 .

Kristen T. Rosenzweig. 2007. Speaking Metaphorically in
Product Design. B.F.A, School of

Design, the Art Institute of Chicago.

Lakoff and Johnsson. 1980. Metaphors We Live By.

University of Chicago press.

MacLean, Paul, 1952. The Triune Brain.

Marcus, Aaron. 1998. Metaphor Design in User Interfaces. Journal of Computer Documentation, Vol. 22. No. 2.

McQuarrie, Edward F. and Mick, David Glen. 1992. On Resonance: A CriticalPluralistic Inquiry into Advertising Rhetoric. Journal of Consumer Research. 19 (September): 180-97.

McQuarrie, Edward F. and Mick, David Glen. 1996. Figures of Rhetoric in Advertising Language. Journal of Consumer Research. 22 (March): 424-38.

McQuarrie, Edward F. and Mick, David Glen. 1999. Visual Rhetoric in Advertising: Text-Interpretive, Experimental, and Reader-Response Analyses. Journal of Consumer Research. 26 (June): 37 -

Michl, Jan. 1995. Form Follows What? The Modernist Notion of Function as A Carte Blanche. Magazine of the Faculty of Architecture \& Town Planning, Yechnion, Israel. Institute of Technology, Haifa, Israel, 10, 20-31.

Mick, David Glen, Burroughs, James E., Hetzel, Patrick, and Brannen, Mary Yoko. 2004. Pursuing the Meaning of Meaning in the Commercial World: An International Review of Marketing and Consumer Research Founded on Semiotics. Semiotica. 152-1/4, 1-74.

Moalosi, Richie, Popovic Vesna ve Hickling-Hudson, Anne, 2007. Culture-orientated Product Design. Industrial Design and Technology Department, University of Botswana.

Monö. 1997. Design for product understanding. Stockholm: Liber.

Narayanan, Srinivas ve Bailey,David. 1997. Characterizing Motor Control Schemas.

Petty, Richard E., Cacioppo, John T., and Schumann, David. 1983. Central and Peripheral Routes to Advertising Effectiveness: The Moderating Role of Involvement. Journal of Consumer Research. 10 (September): 135-46.

Reddy, Michael J. 1993. The Conduit Metaphor: A Case of Frame Conflict in Our Language About Language. Metaphor and Thought. Second Edition. Cambridge University Press.

Roehm, Michelle L. and Sternthal, Brain. 2001. The Moderating Effect of Knowledge and Resources on the Persuasive Impact of Analogies. Journal of Consumer Research. 28 (September): 257-72.

Russell, Bob and Novosedlik Will. 1998. Design Matters: New iMac Apotheosis of Lateral Thinking. Strategy. 25, 22-23.

Sara Ilstedt Hjelm. 2002. Semiotics in Product Design, ISSN 1403 - 0721 (print) 1403 - $073 \mathrm{X}$ (Web/PDF), September.

Saussure. 1916/1983. Course in General Linguistics, London: Fontana/Collins.

Unnava, H. Rao and Robert E. Burnkrant. 1991. An Imagery Processing View of the Role of Pictures in Printed Advertising. Journal of Consumer Research. 28 (May), 226-31. 
Vervaeke, John ve M. Kennedy, John. 2004. Conceptual Metaphor and Abstract Thought. Psychology University of Toronto.

Veryer, Robert W. and Hutchinson, J. Wesley. 1999. The Influence of Unity and Prototypicality on Aesthetic Responses to New Product Designs. Journal of Consumer Research. 24 (March), 374-94.

Veryzer, Robert W. 1997. Measuring Consumer Perceptions in the Product Development Process. Design Management Journal. (Spring): 66-71.

Xiaoyan Deng. 2006. Exploring Metaphoric Product Design. Marketing Wharton U. Penn.

http://www.rhetorosaurus.co.uk/rhetoric/base/essay-aristotleon-metaphor.asp

Buccino G., Binkofski F., Fink G.R., Fadiga L., Fogassi L., Gallese V., Seitz R.J., Zilles K., Rizzolatti G., and Freund H.-J. 2001. Action Observation Activities Premotor and Parietal Areas in a Somatotopic Manner: An fMRI Study. European Journal of Neuroscience. 13:400-404.

Hawkins J. and Balekslee S. 2004. On Intelligence. Times Books. bölüm 2 ve 3 .

Tettamanti M., Buccino B., Saccuman M., Gallese V., Danna M., Scifo P., Fazio F., Rizzolatti G., Cappa S., and Perani D. 2005. Listening to Action-Related Sentences Activates FrontoParietal Motor Circuits. Journal of Cognitive Neuroscience. 17:273-281.

Gentner D., Bowdle B., Wolf P., Boronat C. 2001. Metaphor is Like Analogy. The Analogical Mind: Perspectives from Cognitive Science. 199-253. Cambridge MA: MIT Press.

Shank, Gary and Gleber, Conrad. 2002. Six Metaphors in Search of The Internet. The Journal of Natural Inquiry \& Refective Practice. Vol. 17, No. 1. Fall.

Koestler A., The Act of Creation, a non fiction book, 1964 Erickson, T.D. 1990. Working with Interface Metaphors. In The Art of Human-Computer Interface Design. Edited by B. Laurel. 65-73. Addison-Wesley.

Kristin H. Lower Gautvik, Towards A Product Language: Theories and methodology regarding aesthetic analysis of design products.

http://design.ntnu.no/forskning/artikler/2001/ Gautvik_I.pdf (2001) 